\title{
The Novel Emerges in Cochinchina
}

\section{JOHN C. SCHAFER and THÉ UYÊN}

$\mathrm{U}$ NTIL RECENTLY, VIETNAMESE SCHOLARS agreed that the modern Vietnamese novel emerged in the North and that the first instances of the genre were Hoàng Ngọc Phách's Tố Tâm (Pure heart) and Nguyến Trọng Thuâat's Qủa dủa đơ (The red melon), both published in 1925. Now it is becoming generally accepted that the Vietnamese novel developed first in the South-in the French colony of Cochinchina, a region that stretched from the modern towns of Biên Hòa and Phan Thiết to Cà Mau, the southern tip of Vietnam. Trần Chánh Chiếu published Hoàng Tố Anb hàm oan (The unjust suffering of Hoàng Tố Anh) in 1910, the same year that another Southerner, Trủong Duy Toản (illustration 1), published Phan Yên ngoai sủ (An unofficial history of Phan Yên). Hồ Biêu Chánh (illustration 2), who was to become the most prolific southern novelist, published his first novel, Ai làm düoc (Who can do it?), in 1912.

Some literary scholars stress continuity. A new genre does not suddenly appear full-blown, they have argued; it emerges gradually in response to changes in economic, linguistic, and cultural conditions. Frequently, predecessor works can be found. Other scholars refuse to see literary history as a story of unbroken continuity. While not denying the principle of intertextuality - that all works relate to prior worksthey emphasize that relations of difference are just as likely as relations of similarity.

When Cao thị Nhu'-Quỳnh and Schafer (1988) looked at the development of the Vietnamese novel in the North, they were persuaded that violent rupture rather than gradual evolution characterized the relation of Hoàng Ngọc Phách's Pure Heart, arguably the first novel published in the North, to its predecessors. After studying the novels of the South, however, the present authors are persuaded that gradual development, not violent disruption, better describes how the novel emerged in this region.

John C. Schafer is Professor of English at Humboldt State University in Arcata, California. Thế Uyên, a writer and scholar, lives in Lacey, Washington.

The research for this article was assisted by a grant from the Joint Committee on Southeast Asia of the Social Science Research Council and the American Council of Learned Societies with funds provided by the Ford Foundation, the National Endowment for the Humanities, and the Henry Luce Foundation. A Luce Junior Faculty Fellowship enabled Schafer to use the John M. Echols Collection on Southeast Asia at Cornell University.

The authors would like to thank Nguyền Văn Trung for making available preliminary reports of the research project that he is conducting in Vietnam on the literary culture of the southern region from 1865 through 1930. The following scholars also provided insights and, helped the authors locate copies of key texts: Bằng Giang, Dỏ Văn Anh, Nguyên Q. Thẳng, and Nguyển Quốc Thái.

The Journal of Asian Studies 52, no. 4 (November 1993):854-884.

(C) 1993 by the Association for Asian Studies, Inc. 


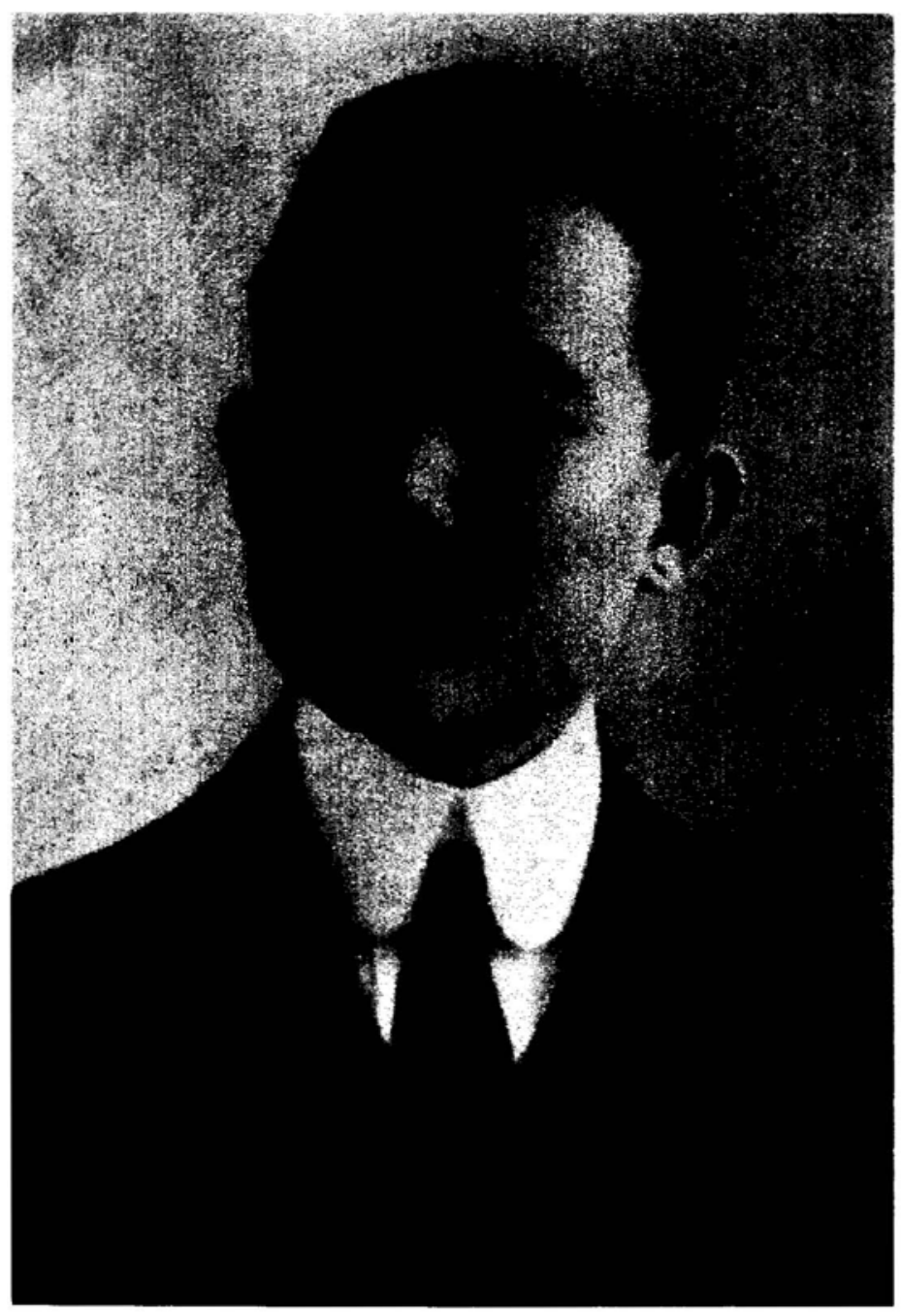

Illustration 1. Trủong Duy Toan (1885-1957), the author of $A n$ Unofficial History of Phan Yên (1910).

In both the North and the South, Vietnam's first novelists were influenced by two indigenous Sino-Vietnamese traditions-knight-errant and scholar-beauty storiesand by French works. The novel emerged first in the South, but the first southern novels did not clash with traditional stories as violently in form and theme as did Hoàng Ngọc Phách's Pure Heart. In discussing the novel's emergence in the South, we will attempt to answer the questions suggested by these facts, namely, why the novel emerged first in the South and why early southern novels were less disruptive of traditional literary values than such a work as Pure Heart.

Literary historians have not addressed these questions because, as has been said, until recently it was commonly accepted that the novel began in the North. Since the 1940s, some Vietnamese scholars have attempted to describe and evaluate the literary achievements of southern writers during the period 1860-1930, but these critical appraisals-mostly short articles, not book-length studies-had little impact: The value of southern literature was not generally recognized, particularly by 


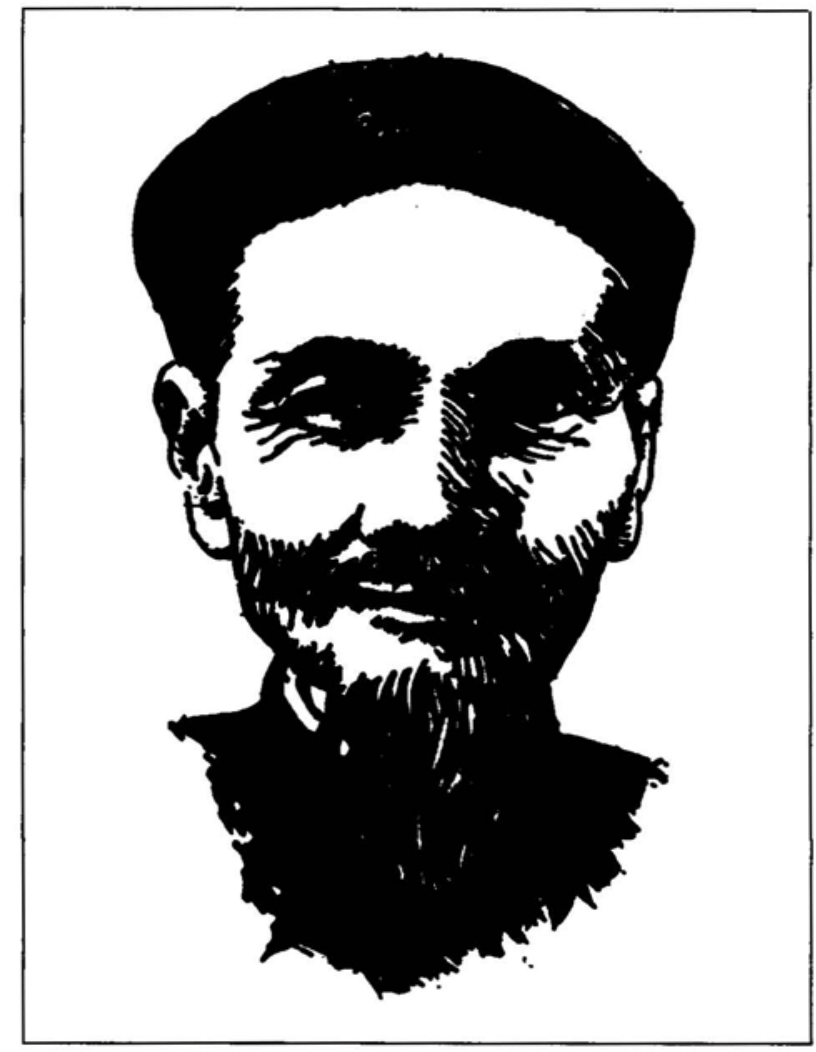

Illustration 2. Hồ Biể Chánh (1885-1958), the most prolific and best-known novelist in Cochinchina.

Vietnamese in other regions. As far as the novel was concerned, Vietnamese scholars and teachers continued to believe that the novel had begun in the North. Almost all the widely read surveys of Vietnamese literature identified Hoàng Ngọc Phách and Nguyến Trọng Thuật as the first novelists. Typically, these surveys, whose authors were northerners, would mention Hồ Bieu Chánh, but slightingly. In his study of contemporary Vietnamese literature, for example, Vũ Ngọc Phan (1941) does discuss Hồ Bieu Chánh-the only novelist from the South that he mentions in his five-volume survey-but finds his works limited by their concentration on characters whose social class and intellects are insufficiently illuminating (1941:361).

Rarely does any survey published before 1987 mention contributions to the novel made by Hồ Bieu Chánh's predecessors. One exception is a literary history by Phạm Thế Ngũ (1965), who mentions Trần Chánh Chiếu's The Unjust Suffering of Hoàng Tố Anb and grudgingly admits that Hồ Bieu Chánh's early works of prose fiction "had all the characteristics of a modern novel," even if they "did not reach a high modern standard of artistic merit" (1965:377-78). After this admission, however, Pham Thế Ngũ incorrectly states that all of Hồ Biêu Chánh's early novels were modeled on French works and that until 1928 he did not begin to produce works with original plots.

In Phạm Thế Ngũ's view, because the South was a new land, a frontier region, it was not fertile ground for literary achievement. Because French culture arrived before scholars could establish a Sino-Vietnamese literary tradition there, he argues, 
all that southerners could produce were popular newspapers and novels easy enough for lower class readers to enjoy (1965:85). Phạm Thê Ngũ's bias against southern literature was shared by other northern critics and helps explain northerners' lack of enthusiasm for the South's early novelists. We will comment later on this bias and suggest some additional causes of this neglect of southern writers.

About six years ago attitudes began to change. In 1987, on the centennial of the publication of Nguyên Trọng Quản's remarkably modern short story, "The Story of Lazaro Phiền," Nguyển Văn Trung issued a preliminary report on Nguyến Trọng Quản and four other southern prose writers. Four other book-length studies have since appeared, all of which acknowledge the contributions to the novel of Hồ Bieêu Chánh and his predecessors (Bằng Giang 1992; Hoài Anh, Thành Nguyên, and Hồ Sĩ Hiệp 1988; Nguyến Q. Tháng 1990; and Trần Văn Giàu, Trần Bạch Đằng, and Nguyến Công Biǹh 1988).

Hồ Biêu Chánh and his circle deserve this belated recognition for what was a substantial accomplishment. They began with the form of narrative bequeathed to them, the verse narrative in $c h \hat{u}$ nôm, or demotic characters, a way of writing Vietnamese with Chinese characters. The verse narrative was itself a Vietnamese adaptation of Chinese scholar-beauty and knight-errant fiction. Gradually they transformed this traditional form into a new Vietnamese genre: the modern novel. In this transformation, they went from verse to prose; replaced historical settings and characters with contemporary ones; abandoned formulaic and explicit transition statements for more implicit, nonformulaic devices; dealt more frankly than had traditional writers with violent passions and crimes-greed, sexual desire, revenge, and murder; and moved from "straight-line narration" of events to a more dramatic and psychological narrative style, a style that included descriptions of scene and the moods of characters.

Before chronicling the novel's emergence in the South, we must discuss two story-telling traditions that antedate the prose novel by many hundreds of years but influenced the course of its development in Vietnam.

\section{The Two Traditions of Knights-Errant and Scholars and Beauties}

Hồ Biéu Chánh and his three pred̦ecessors were all fluent in French and familiar with French novels. In fact, Hồ Biéu Chánh and Trần Chánh Chiếu wrote novels modeled on French works, but the Vietnamese novel was as much a product of indigenous development within the Sino-Vietnamese tradition as it was the result of Western influence. Two types of Chinese stories-stories of knights-errant ( $y u$ bsia or hsia-k'e; Vietnamese: biẹp-khách) and scholar-beauty stories (ts'ai-tzu chia-jen; Vietnamese: tai-tú giai-nbân)-are important prior texts for the early Vietnamese novel. According to James Liu (1967), historical knights-errant first appeared in China during the Warring States period (403-221 B.C.). Fictional accounts of their exploits date from the third century B.C. The heroes of these knight-errant fictions traveled from place to place exhibiting $y i$ (Vietnamese: nghia), or righteousness, by helping the poor and distressed and spurning all material rewards. This $y i$ that the knight errant devoted his life to resembled the Confucian jen yi (nhân nghia), but unlike the Confucian virtues and bonds, which stressed duties to family, the $y i$ of the knight-errant compelled him to assist strangers as well as relatives. Unlike the heroes of the classical prose romances such as The Three Kingdoms, the typical knight- 
errant did not lead armies into battle but acted individually, often rebelling against the established authority of the state (Liu 1967:1-8; 81-82).

The term "scholar-beauty story" refers to a collection of over fifty works of prose fiction that became popular reading in seventeenth-century China. These stories resemble knight-errant stories in many respects, and some stories, for example, Hua-t'u yuan (Portraying marriage) and Hao ch'iu chuan (The happy union), have elements of both traditions. But generally the heroes of scholar-beauty stories are handsome poets who distinguish themselves in poetry contests and in quiet acts of mental courage; knights-errant, on the other hand, must often exhibit physical prowess. Hessney offers this definition of scholar-beauty stories: "sentimental fictions of novel length, primarily devoted to the themes of talent, beauty, and love, which flourish in the early Ch'ing period and incorporate features associated with both the romance and the novel in the West" (1979:31). The plot of scholar-beauty stories, Hessney explains, can be reduced to the formula: "scholar meets beauty, falls in love, overcomes obstacles, passes official examinations, marries her, and they live happily ever after" (1979:32).

Scholar-beauty stories resemble Chinese classic romances such as The Three Kingdoms, The Water Margin, and The Dream of the Red Chamber in certain respects. Like these works, scholar-beauty stories were usually set during a specific historical period. The action of $Y u$ chiao li (The two cousins), for example, occurs in 1449 in the mid-Ming period after the execution of the powerful eunuch Wang (Hessney 1979:285). Scholar-beauty stories also used rhetorical formulas similar to those used in the classic romances. Chapters begin with two syntactically parallel lines of verse that announce key events in the coming chapter. Formulaic language is used to mark shifts in the plot ("Rather than relate what happened next, we will instead tell of . . . "). Scholar-beauty stories were, like the classic romances, linked-chapter (chang-bui; Vietnamese: chüong-hồ) stories: the action at the end of one chapter was continued in the next; and each chapter ended with the formula: "If you want to know what happened next, please listen to the next chapter" (Hessney 1979:28283).

The plots were somewhat rambling and episodic but not as much as the plots of the classic Chinese romances. Despite the many obstacles that authors of scholarbeauty stories construct to keep their hero and heroine apart and prolong the tale, the plot moves linearly (and inexorably) toward a clear climax and resolution, one that almost always involves the marriage of the beauty to the scholar. Unlike the classic Chinese romances, which describe the rise and fall of social groups, scholarbeauty stories focus on a limited number of protagonists-usually only two, a hero and a heroine. Henry comments that because they do have more concentrated plots, the scholar-beauty stories more closely resemble many early English novels than do the long and rambling classic Chinese romances (1984:63), a point that we shall return to later.

Hồ Biêu Chánh and many other Vietnamese of his generation learned Chinese in traditional village schools and would have read knight-errant and scholar-beauty stories in Chinese, but most southerners would have been exposed to these two

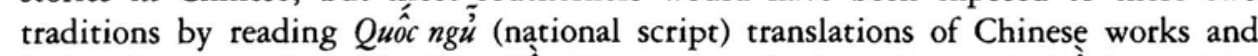
by hearing or reading Kim Vân Kiều ([The story of] Kim, Vân, and Kiểu), Luc Vân Tiên ([The story of] Lục Vân Tiên), Nhị độ mai (Twice-blooming plum flower), and other Vietnamese truyện thỏ nôm (verse narratives in $c h \hat{u}$ nôm), a Vietnamese genre heavily influenced by the knight-errant and scholar-beauty traditions. When, beginning in the $1880 \mathrm{~s}$, knowledge of $Q u \hat{i} c$ nguे became more widespread, the well-known verse 
narratives were among the first works to be transcribed and printed in the new script.

The two best-known verse narratives are Nguyê̂n Du's Kim Vân Kiều (ca. 1800) and Nguyên Đình Chiểs Lục Vân Tiên (ca. 1860). The latter contains elements of both the knight-errant and scholar-beauty traditions: Luc Vân Tiên, the hero, is a fighter and rescuer of those in distress as well as a scholar. Kim Vân Kiều is a scholar-beauty story but an unusual example of its type. In a decision that greatly influenced the course of storytelling in Vietnam, Nguyến Du chose as his model a rather atypical example of the scholar-beauty genre- a late seventeenth-century story entitled Chin Yun Cb'iao chuan, or The Story of Chin, Yun, and Cb'iao, one of fifteen scholar-beauty stories that had prefaces written by the Master of T'ien-hua Library (T'ien-hua ts'ang chu jen) (Henry 1984:63). Nguyên Du made only minor adjustments in the plot: the events in his Kim Vân Kiêu are the same as those in the Chinese story. A beautiful girl (Ts'ui-ch'iao), adept at music and writing poetry, meets a handsome scholar (Chin Chung). The two secretly become betrothed and then Chin Chung, the handsome scholar, must leave on a trip to tend to some family business. When he returns four months later, he learns that Ts'ui-ch'iao has been forced to become the concubine of a merchant to save her father, who has been unjustly accused by a local magistrate. She has left a message urging Chin Chung to marry her younger sister, Ts'ui-yun, which he does, but he keeps looking for 'Ts'ui-ch'iao. When he finally finds her sixteen years later, after he has become a degree-holder and an official, she becomes his second wife but exacts from him an agreement never to consummate their marriage.

This plot marks Chin Yun Ch'iao chuan as a typical scholar-beauty story. Certain elements, however, make it unusual. As Henry (1984) points out, Chin Yun Ch'iao chuan presents a less polite and less idealized portrait of society than was usual for the genre. The chief protagonists come from families whose social standing is more humble than that of the families of typical heroes and heroines in scholar-beauty stories. Thus their behavior is not as refined as the behavior of more typical scholars and beauties. In their second secret meeting, Ts'ui-ch'iao must cool Chin Chung's ardor by alluding to a story of two famous lovers who doom their love affair by consummating it prematurely. At one point, Ts'ui-ch'iao abandons restraint and throws herself into her lover's arms. Henry points out that Chin Yun Ch'iao cbuan creates an atmosphere of "barely controlled desire" not found in the typical scholarbeauty story. The Confucianism evoked is "not the pure, muscular Confucianism" of the scholar-beauty story Hao-ch'iu chuan (The happy union), for example. The "prevailing ideology" of the story, Henry argues, is not Confucian but rather "a blend of Buddhism with spiritualism" (1984:67). Buddhism warns against passionate attachments to the things of this world. Therefore, Ts'ui-ch'iao's sensitivity, beauty, and capacity for intense love doom her to a life of suffering. Ts'ui-ch'iao becomes the embodiment of the notion that beauty and talent are linked by fate with misfortune. She thus symbolizes the well-known expression, bung yen po ming (Vietnamese: hồng nhan bac mệnh): Beautiful women will suffer a perilous fate.

There are other non-Confucian themes that make Chin Yun Cb'iao chuan an unusual scholar-beauty story. During the sixteen years of her separation from Chin Chung, Ts'ui-ch'iao travels through a world far removed from the polite and sheltered society frequented by heroines of more typical scholar-beauty stories. She becomes, in turn, a prostitute, concubine, domestic, Buddhist nun, prostitute again, wife of a rebel chieftain, prisoner of war, Buddhist nun again, and finally the second wife of Chin Chung. Henry suggests that we see Chin Yun Ch'iao chuan as the union of a "framing story," the typical scholar-beauty plot, with an "adventure story," the 
account of the heroine's experiences in the underworld of Chinese society (1984:68).

This, then, was the tale that Nguyên Du chose as the model for his masterpiece,

Kim Vân Kiêu. The work he fashioned based on this relatively unknown Chinese story became the most loved and respected work in the Vietnamese language. It became so popular that no Vietnamese who wrote after its appearance around 1800 could ignore its influence.

How did Kim Vân Kiều and other stories from the two traditions we have described, that of knight-errantry and that of scholar-beauty stories, prepare or not prepare Hồ Biè Chánh and his circle for writing modern novels? First, most stories in these two traditions were, like the modern novel, fairly realistic. Heroes and heroines may perform remarkable feats, but their actions remain within the realm of the possible. Vietnamese audiences have a strong taste for the supernatural, making it tempting for authors to inject supernatural elements. These two traditions, however, discouraged supernaturalism and presented models for realistic narration. Second, their shorter length and relatively unified plots made knight-errant or scholar-beauty stories better models for aspiring novelists than a long, episodic historical romance such as The Three Kingdoms.

Third, the modified Confucianism of a scholar-beauty story, Nguyến Du's Kim Vân Kièu, for example, with its emphasis on Buddhist as well as Confucian themes, opened up possibilities for Vietnam's early novelists: It provided literary sanction to deal more boldly with less refined topics like sexual desire. Hồ Biêu Chánh persistently supported Confucian doctrine in his novels, but he acknowledges the existence of more earthly desires than a pure passion for Confucian virtue. The "atmosphere of barely controlled desire" that is present in some nineteenth-century works becomes uncontrolled desire in Hồ Biê Chánh's verse narrative, $U$ tinh luc (Story of secret love), and his early novels. In both his verse narrative and his first novel, the hero and heroine indulge in premarital sex; in his second novel a woman is raped; and in his fourth a young girl is seduced and made pregnant by her first cousin, who is already married and who was raised by the girl's mother, giving the seducer's actions the quality of incest. In distinguishing the English novel from perhaps its most important predecessor, the romance, Davis explains that while the romance stressed the preservation of virtue and chastity, the novel featured "illegal doings and forbidden passions" (1983:40). Nguyênn Du's narrative, in which the heroine loses the battle to retain her chastity and travels through the underworld of Chinese society, suggested a host of novelistic possibilities to Vietnam's early southern novelists. ${ }^{1}$

Finally, the knight-errant tradition provided Vietnam's first novelists with different models for settings, characters, plots, and themes from those found in scholar-beauty stories. Knight-errant stories take their characters out of upper-class courtyards to travel the countryside looking for wrongs to right. They required characters more robust than the typical scholar hero. The knight-errant tradition sanctioned themes such as revenge, which Confucian heroes were supposed to suppress in favor of forgiveness. Vietnam's first novelists in the South were attracted to French novels of adventure by Alexandre Dumas père, Victor Hugo, and Hector Malot, and chose them to translate and use as models in part because the knight-errant tradition had familiarized them and their readers with similar motivations in fictional characters.

${ }^{1}$ In Lê Hoằng Mủu's Oán hồng quần (Beautiful women are resented) (1918), for example, the heroine is imprisoned for months in a Saigon brothel. To convince her to cooperate, she is shown the corpse of a girl who refused to entertain customers. The author refers to Kim Vân Kiều continually and echoes many lines from Nguyển Du's poem. 
But Cochinchina's first novelists also had to set aside some features of the knighterrant and scholar-beauty traditions. Stories in these traditions were retellings and elaborations of historical incidents. Modern novelists prefer to set their stories in their own time and country. Too, the style of works in these traditions was far removed from that of the modern novel. Most Chinese knight-errant and scholarbeauty stories were written in a composite style, a mixture of pai-bua (vernacular style) and wen-yen (literary style). When Chinese writers wrote in a more literary style, their sentences became more implicit, more parallel in structure, and more likely to contain ornate diction and literary allusions (Crawford 1972:16-52). The acceptance by both traditional Chinese and Vietnamese writers of what Crawford calls "implicativeness" (a tendency to suggest rather than to explain) as a literary value discouraged Vietnam's first novelists from developing the kind of full description of mood, character, and scene that we associate with the Western novel. Thúy Kiều and Kim Trọng, the lovers in Kim Vân Kiều, share what critic Nguyền Huệ Chi calls "a wordless love," one that neither they nor the narrator of the poem explain or analyze (1986:131). Tố Tâm and Đạm Thủy, the lovers in Hoàng Ngọc Phách's Pure Heart, on the other hand, explain and analyze their love in great detail, and this is one of the reasons the novel created such a sensation.

Because the authors of knight-errant and scholar-beauty romances valued ornateness, their works did not encourage the development of prose styles that resembled actual speech, a characteristic of the Western novel. The knight-errant and scholar-beauty traditions were transmitted to Vietnamese primarily through verse narratives. Because implicativeness and ornateness are valued more highly in poetry than prose, this Vietnamese preference for verse meant that these two literary values were more firmly entrenched in Vietnam than in China. Hồ Bieu Chánh and his circle were bucking powerful preferences when they began to experiment with descriptive and vernacular styles. Their struggle to abandon implicativeness and ornateness is revealed in their early works, particularly in Hồ Bièu Chánh's later revision of his first novel, Who Can Do It?

\section{Moving toward the Novel: Hồ Biêu Chánh's Story of Secret Love}

Having touched on the literary tradition available to Hồ Biêu Chánh and his circle, we will now look more closely at his life and describe how he moved from verse narrative to novel. Hồ Văn Trung, who later adopted the pen name Hồ Biè Chánh, was born in 1885 in the village of Bình Thành, Gò Công Province, the son of a village chief. At the time of his birth, south Vietnam had been a French colony for eighteen years. Athough the study of Chinese was in decline, some families continued to make sure their sons learned Chinese. When Hồ Biêu Chánh was eight years old, he began studying Chinese with a village teacher. In 1896 he entered the Franco-Vietnamese school system and began learning French and Quố ngû. He progressed through the system, moving to new towns to enter higher level schools. He obtained a scholarship to study at the secondary school in Mỹ Tho and then gained entrance to the prestigious lycée ChasseloupLaubat in Saigon, from which he received a Diplome de fin d'études in 1905. In 1906 he passed a test to become a civil servant and began what was to be a thirtyfive-year period of service for the French colonial government. He held a variety of posts in different towns and districts in the Delta, earning the respect of both his 
colonial bosses and his own people. When he retired in 1941, the French awarded him the Chevalier de la Légion d'Honneur. Many Vietnamese civil servants in the colonial administration took advantage of their positions to line their own pockets. Hồ Biêu Chánh, however, was an exception: He earned a reputation as a fair and honest official (see Huỳnh Minh 1969:123-27; Nguyên Khuê 1974; and Thanh Lãng 1967:551-59).

Like most Vietnamese novelists, Hồ Biêu Chánh was also a journalist. Along with a group of other southerners, he published a newspaper in Long Xuyên in 1918, the Đại Việt Tạp Chí (Vietnam Journal), and helped to found several other papers as well. Frustrated with the censorship imposed by the colonial authorities, he decided in 1925 to give up journalism and make the writing of novels his main after-work activity. Hô Bieu Chánh was interested in moral reform, not political resistance, so his novels describe extreme suffering caused by poverty, greed, and corruption but suggest no political solutions. In fact, Hồ Bieu Chánh urges a reaffirmation of traditional Confucian virtues.

Hồ Biêu Chánh's reputation has been hurt, particularly in the eyes of resistanceoriented scholars, by two decisions he made in the 1940s. In 1942 he accepted money from the French to start two newspapers that sang the praises of Marshal Petain and the Vichy government program in Indochina and Europe. And in 1942 he became an adviser to Nguyền Văn Thinh, a man selected by the French to be president of a provisional government of Cochinchina. Because forming this government violated a previous agreement to hold a referendum on the future of Cochinchina, many Vietnamese considered Thinh a traitor (see Huỳnh Minh 1969:125-26 and Nguyển Khuê 1974:49-77).

Hồ Bieu Chánh's first narrative, $U$ tình luc (Story of secret love), ${ }^{2}$ is clearly a transitional work with some elements of the traditional verse narrative. Although written in 1909, the earliest known published edition is dated 1913. The most obvious traditional feature of this narrative is its form-the fact that it is written in alternating lines of six, then eight syllables, the form used by Vietnamese for short (two to four lines) folk poems called $c a$ dao as well as for verse narratives. This was the form used by Nguyên Du in Kim Vân Kiều, and Story of Secret Love provides a good example of how vividly the lines from this nineteenth-century masterpiece resonated in the minds of Vietnam's first novelists. In Story of Secret Love, Hồ Biêu Chánh often echoes lines from Kim Vân Kiều. For example, his thirteenth line, "Trải qua mấy cuộc đoạn trủờng" (Having endured many heartrending events), echoes the third line from Nguyền Du's masterpiece, "Trài qua một cuộc bể dâu" (Having endured a terrible upheaval).

The plot of Story of Secret Love resembles in broad outline the plot of a typical scholar-beauty story: A promising scholar meets a beautiful girl, they become betrothed, then endure a period of separation caused by the schemes of the villain, but finally are joyfully reunited in marriage. The villain of Story of Secret Love is a woman who is a rival for the affections of the scholar; she contrives a letter that asserts that the beauty has behaved improperly with another man. When the scholar sees the letter, he sets off for the North. While separated, both lovers endure various calamities before they are joyfully united and married, and the poem concludes.

Like the plot, the themes and characters of Story of Secret Love also resemble those found in the nineteenth-century verse narratives. Heaven's control over human

${ }^{2}$ We have not been able to locate the complete text of this poem. Our analysis is based on extensive excerpts printed in Nguyê̂n Khuê (1974:149-58) and Phạm Việt Tuyền (1971:85-112). We also have profited from the critical commentary provided by these two researchers. 
affairs, especially affairs of the heart, and the Confucian virtues of loyalty, filial piety, and human righteousness are emphasized. Though the characters of Story of Secret Love are in some respects more complex than those in traditional verse narratives, they are easily divided into good and bad, with the former rewarded and the latter punished. In other words, Story of Secret Love has a traditional ending, or hâu, the mechanism that Chinese writers of scholar-beauty stories and Vietnamese writers of verse narratives employed to further their didactic purposes.

But there are some modern elements as well. Nineteenth-century verse narratives were written in chü nôm (demotic characters), but Story of Secret Love was composed in $Q u \hat{o} c n g \hat{u}$, the new national script. This was a significant innovation for several reasons. Chu nôm is a complex writing system that Vietnamese have used since at least the thirteenth century to write the Vietnamese language. It consists of Chinese characters employed as both phonetic and semantic indicators to represent Vietnamese words. To read and write chûu nôm, one had first to master Chinese. Therefore, only the Vietnamese literati knew chü nôm. The absence of a more easily learned writing system is one explanation for the novel's late arrival in Vietnam. Because they contained many mnemonic devices (rhyme, regular meter, parallelism), verse narratives could be easily memorized and would circulate among non-literate Vietnamese. Lacking these devices, long prose narratives could not be memorized and therefore were not produced until a script more easily learned than $c h \hat{u}$ nôm was devised.

French missionaries developed a script as early as 1651 , but Vietnamese writers did not begin to use it extensively until the beginning of the twentieth century. Although it was a, workable and easily learned system, an alphabetic script using roman letters, Quî́c ngǘ, or National Script, caught on slowly for several reasons. French missionaries made little effort to promote it outside the Catholic community. French colonial administrators could not agree as to whether $Q u \hat{o} c$ ng $\tilde{u}$ or only French should be taught in government schools; their vacillation retarded its spread. Finally, many Vietnamese, at first, avoided Quố ngư because they perceived it as a tool of French oppression (DeFrancis, 1977:48-66; 136-40).

When knowledge of Quố ngu spread rapidly in the 1880s, Vietnamese began to transcribe Vietnamese works written in $c h \tilde{u}$ nôm into this new, more easily learned script. Quî́c ngü versions of the popular Vietnamese verse narratives Kim Vân Kiều, Luc Vân Tiên, and Nhị độmai appeared at this time, for example. Vietnamese also translated Chinese stories, including the long romances like States of the Eastern Cbu Dynasty and The Three Kingdoms, and published them in Quoc ngü editions. Hồ Biêu Chánh himself translated a collection of Chinese short stories, Tân soan co tích (New collection of old stories), in 1910. It is clear from the prefaces to the early novels and from articles in newspapers that southern readers quickly grew tired of stories translated from Chinese and began to hunger for stories about events in their own country.

In deciding to write his verse narrative Story of Secret Love in Quî́c ng $\tilde{u}$, Hồ Biẻ Chánh was reacting to the growing popularity of the new script. Other innovative features found in Story of Secret Love were responses to his audience's demand for Vietnamese stories, a demand fueled in Vietnam by ethnic pride and anti-Chinese sentiment. Vietnamese of Hồ Bieu Chánh's generation (arguably of all generations) had a complex love-hate relationship with the Chinese: They respected the Chinese as the inheritors of a rich literary culture but resented their dominance in economic matters. It is difficult to find an issue of a southern newspaper printed during this period that does not have an editorial bemoaning the commercial power of the Chinese and urging Vietnamese to band together to combat it. Anti-Chinese slogans 
and hortatory expressions were sometimes printed in big type at the bottom of newspaper pages. For example, in the newspaper Nông Cố Min Đàm (News on agriculture and commerce), beneath a regular installment of Hồ Bieu Chánh's first novel, Who Can Do It? , the following statement appears: "Any Annamese [Vietnamese] who sees a Chink [chệc] discriminate against us and does nothing about it has accepted his status as a slave" (February 5, 1920). Beneath another installment appears this slogan: "Try to make a living through business. Don't let our money go to China. Come on, brothers and sisters!" (September 18, 1919). Hồ Biêu Chánh reveals in his introduction to Story of Secret Love that a desire to prove that Vietnamese were equal to Chinese was one of the forces pushing him to write his poem:

Having endured many heart-rending events,

Vietnam doesn't lack those who are as good as Chinese,

But some look down on what is theirs,

Quickly praising the things of others, ridiculing their own;

Because I'm angry I must speak out,

Compose a few rough verses and let others decide their worth.

(lines 13-18)

To accomplish his task, Hồ Biê Chánh created a hero and heroine of Story of Secret Love who come from an actual district in Gia định Province, one of the six provinces in the Delta. Tấn Nhỏn, the hero, studies in $\tilde{M} y$ Tho; the heroine suffers in Saigon. The story takes place in 1880 - the very recent past for Hồ Bieu Chánh and his readers. Later in his novels, Hồ Biêu Chánh does much more than simply set his stories in the world of Cochinchina at the turn of the century: He recreates that world-captures in print the way of life of Vietnamese from the small towns and villages of the Delta region. As he recreates that world, he exposes the greed and corruption of district officials and rich landowners, the miserliness of Chinese and Indian usurers, and the problems that arise when parents force their daughters into marriages solely to further the family's economic fortunes. Story of Secret Love contains only hints of talents more fully displayed in later works. But in this narrative Hồ Bieu Chánh begins to move storytelling away from the two traditions of knighterrant and scholar-beauty stories and pushes it toward the modern novel. It seems likely that his innovations in the matter of setting were motivated not primarily by a desire to imitate Western-style novels but rather by the wish to satisfy a readership that was demanding stories about people like themselves-Vietnamese stories.

Hồ Biêu Chánh also began to experiment with characters who differ from those found in the traditional verse narratives. Sometimes the hero and heroine of Story of Secret Love act like the idealized exemplars of Confucian virtues found in nineteenthcentury Vietnamese works, such as, for example, the always proper Lục Vân Tiên and Kiều Nguyệt Nga in Luc Vân Tiên. But Hồ Biêu Chánh's characters also give in to urges - including sexual urges-and exhibit some of the passions and frailties of ordinary men and women. In traditional stories female chastity was highly honored. It is true that Thúy Kiều in Kim Vân Kiều loses her chastity early in the tale, but Nguyên Du's poem was, as we have pointed out, an atypical verse narrative. And Thúy Kiều becomes a concubine for a good reason: to get her father out of prison. She is torn by two very Confucian bonds and duties-filial piety (biếu) for her father and love (tinh) for the man to whom she is secretly betrothed-and she decides in a conscious and rational manner that the father-daughter bond is the weightier one. In Story of Secret Love, however, the hero and heroine are simply overcome by passion 
and cannot control themselves. Even before he turned from verse to prose, Hồ Bieu Chánh was demonstrating some very modern and novelistic tendencies in his treatment of the sexual relationships of his leading characters.

Hồ Biêu Chánh certainly was not the first Vietnamese writer to deal frankly with sexual matters. In the North, Hồ Xuân Hủong (early nineteenth century) carefully crafted poems with double meanings; one of the meanings was often a bold treatment of some sexual topic. In both the North and the South, folk poetry and songs dealt frankly with sexual issues. In literary narratives, however, even, for example, Kim Vân Kiêu, which features scenes in brothels, sexual matters were treated with considerable delicacy. This delicacy was achieved in part by the poet's use of esoteric diction and timely allusions to Chinese classics.

But in the South there also existed a more folk version of the Vietnamese verse narrative, usually called simply tho (poem) or truyện (story), which treated sexual matters more frankly (see Buì Đúc Tiṇh 1974:183-226 and Nguyê̂n Q. Thắng 1990:195-204). These tho, or story poems, like the more literary verse narratives, obeyed intricate rules for rhyme and meter but were composed in a much less esoteric style and therefore were easily appreciated by common people. Unlike the literary verse narratives, whose plots came from Chinese history and literature, these simpler story poems were accounts of events - often very recent events-that took place in Vietnam. Because some story poems contained only thinly disguised anti-colonial messages or depicted incidents of anti-French violence, they were banned by the French authorities. Sáu Trọng, for example, is an account of a man (Sáu Trọng) whose wife leaves him to marry a French clerk and also has affairs with Sáu Trong's close friend and her nephew before Sáu Trong decides enough is enough and kills her. In Thầy Thông Chánh (Interpreter Chánh) the hero, an interpreter, shoots a French prosecutor who had seduced his wife. The diction and style of Hồ Biêu Chánh's Story of Secret Love mark it as a verse narrative, but its contemporary setting and sexually unrestrained characters link it to the southern tradition of the story poem, a tradition that clearly influenced Vietnam's first novelists.

\section{Hồ Biêu Chánh's First Novel, Who Can Do It?}

In 1912 Hồ Biẻ Chánh went to work in Cà Mau, at the southernmost tip of Cochinchina. It was here that he made his important decision to switch from verse to prose and to try his hand at novel writing. He explains his decision in a brief autobiographical sketch that appears in many editions of his novels:

At that time Trần Chánh Chiếu published Hoàng Tố Anb hàm oan, the first novel in the Six Provinces. It was a love story that described characters from the region and was written in prose. After reading this book I felt that it was easier to move people in prose [than in verse], and so when I went to work in Cà Mau in 1912, I wrote Ai làm düọc, the first novel written in prose in Cà Mau featuring people from Cà Mau as characters.

Ai làm düọc (Who can do it?) has some traditional features, but it is certainly a novel, if by novel one means a long narrative in prose set in the time and locale of the author. The plot is traditional-reminiscent of scholar-beauty and knighterrant stories. A struggling scholar-turned-clerk falls in love with a strong-minded 
and virtuous daughter of a well-to-do district chief. After surviving separation and poverty brought on by the evil machinations of a cruel stepmother, the hero and heroine settle down peacefully in Cà Mau. We have, in other words, the typical protagonists and the traditional tripartite structure: meeting-separation/sufferingjoyful reunion. Another traditional feature is a subplot involving another couple who, like the hero and heroine, experience trials and separation before joyful reunion. This interweaving of the stories of two couples was common in the scholar-beauty tradition.

Hồ Bieu Chánh divided his first novel into twenty-seven sections of about a thousand words each. These sections were traditional and not an adapatation to journalistic demands. When Who Can Do It? was later (1919) serialized in a southern newspaper, the printed installments did not correspond to these divisions. Each section has the traditional heading that captures in brief what will occur in the section: "Grandfather and Granddaughter Meet," "Husband and Wife Separate," "Return to Saigon," etc. Who Can Do It? also has the traditional explicit, formulaic transitions that were used by Chinese and Vietnamese authors of scholar-beauty stories. For example, when the hero decides to ship off to the Indian Ocean to look for precious stones, leaving the heroine sad and frustrated, we encounter these sentences at the start of a section (16) entitled "Return to Saigon": "There is still a lot to tell about Chí Đaii's [the hero's] trip to the Indian Ocean to supervise divers looking for precious stones. But now [I] will tell you about Bạch Tuyêt [the heroine] who from the time her husband left became sadder and sadder."

In theme, too, Who Can Do It? is traditional. Though the hero and heroine suffer terribly, particularly when their child dies because they lack money for proper medical care, the novel does not encourage readers to blame anyone but the evil stepmother and to a lesser extent her husband, the heroine's father, who should have realized what his wife was up to. In other words, unlike Hoàng Ngọc Phách's Pure Heart, Hồ Bieu Chánh's first novel did not explicitly or implicitly attack the Confucian system of moral values. The objects of Hồ Bieu Chánh's attack are greed and selfishness, not Confucianism.

Who Can Do It? does, however, embody some significant departures from traditional narrative forms. The title, in the form of a question (although no question mark appears in Vietnamese), is nontraditional and a trifle ambiguous: It is generally understood to mean, "Who can do both the good and bad deeds depicted in the story?" A more important innovation, however, was Hồ Bieu Chánh's decision to tell his story in prose, not verse. The style of the prose, too, is very close to ordinary southern speech. The characters do not quote poetry, nor do they speak in lofty poetic phrases. Instead they speak directly and simply in the accents of the Cà Mau region. Although the characters and plot are traditional in some respects, they are quite modern in others. As in Story of Secret Love, the hero and heroine engage in premarital sex, although this lapse is not presented as a sudden surrender to passion, as it was in Hồ Bieu Chánh's verse narrative: In Who Can Do It? circumstances force the couple to begin living together.

A brief summary of the plot will make these circumstances clear. To ensure that she inherits her husband's wealth, the stepmother, who has already poisoned the family's real mother, plans to arrange a marriage between her stepdaughter, the heroine, and her nephew. Fearing (correctly) that her stepdaughter and the hero are growing fond of each other, she urges her husband to fire the hero from his job as clerk and immediately arrange a marriage between his daughter and her nephew. The hero leaves Cà Mau and soon the heroine, under pressure to marry a man she despises - the nephew of the woman she knows murdered her mother-flees in 
search of the hero. She finds him, and they head for Saigon, where they set up housekeeping together and begin a period of intense suffering. The hero ends up working as a rickshaw driver; the heroine has a baby, then becomes sick, and the baby dies.

Finally, the heroine's grandfather finds them, arranges for them to be properly married, and convinces the proud hero to accept some financial assistance. When the hero gets a job on a ship going to India to dive for precious stones, the heroine finds it impossible to live comfortably at home while her husband is enduring hardships at sea, and so she returns to Saigon. Her father and stepmother, who have been searching for her (the stepmother wants her near so she can more easily dispose of her), finally find her in Saigon and take her back to Cà Mau, where the stepmother tries to poison her. The stepmother is foiled by the hero, who returns just in time to save his wife. The stepmother is sent to jail, and the heroine's father regrets his lapses. The couple of the subplot, who have helped the protagonists in their period of suffering, marry. The novel ends with a flash-forward five years ahead, which informs the reader that the two couples each have had two children and are living happily in Cà Mau, where the hero and his friend have become the richest men in the region.

Like the heroine of the traditional verse narrative Kim Vân Kiè̀u, the heroine in this novel endures a long period of suffering. In Hồ Bieu Chánh's account, however, the suffering occurs not in China in distant times but in Vietnam, especially in Saigon, where the heroine and her husband fall victim to uncaring employers, cruel Chinese usurers, and other afflictions that prey on the poor in a modern urban environment. Hô Bieu Chánh's Who Can Do It? is part love story and part adventure story, but it is also a realistic portrait of life in Cochinchina at the turn of the century. In this sense, it contrasts sharply with nineteenth-century verse romances like Kim Vân Kiều and Lục Vân Tiên.

\section{Tố Tâm (Pure heart) and Ai làm đựoc (Who can do it?)}

Who Can Do It? also contrasts sharply with Hoàng Ngọc Phách's Pure Heart, published in Hanoi in 1925 and long considered the first Vietnamese novel. The latter was the novel that shocked some readers and entranced others, particularly young women, when it appeared on the Hanoi literary scene. Pure Heart, which takes place in Hanoi at the time of the author, is the story of a twenty-year-old woman who falls in love with a university student and refuses to give up her love even after she learns that his parents have arranged for him to marry another woman. Eventually, the heroine gives in to family pressure and marries someone else. After extreme mental and physical suffering, she dies of pulmonary tuberculosis brought on by a broken heart.

Pure Heart does have traditional elements. It can be seen as an adaptation of the scholar-beauty story: The hero is a scholar, the girl is beautiful and talented, they both read and write poetry, they meet, then complications set in, etc. In fact, Hoàng Ngọc Phách's refined, poetry-quoting characters are closer to characters in the Chinese scholar-beauty stories than are Hô Bieu Chánh's more earthy protagonists. But Pure Heart's traditional elements are overwhelmed by modern features, the most important being Pure Heart's relentness concentration on the subjective experience 
of the two lovers. The two lovers suffer the intense agonies of their socially forbidden love and analyze their moods and feelings in great psychological detail. The novel's point of view-part first person account, part epistolary novel, part diary-provides the reader direct access to the thoughts and feelings of the protagonists. Pure Heart is a much more psychological novel than Who Can Do It?

Although the author did not fully intend it, Pure Heart also begins to mount an attack against Confucian morality. In his preface, Hoàng Ngọc Phách offers his heroine as a model of Confucian virtue. It is true that the heroine exhibits filial piety by obeying her mother and marrying someone she does not love, but she also proves willing to elevate temporarily the idea of individual happiness above family harmony. It was this willingness that entranced or shocked readers. In structure, too, Pure Heart departs from accepted practice. It lacks the traditional hậu, the happy ending in which the good are rewarded and the villains punished. The heroine dares to question traditional Confucian moralty, and her punishment is a slow death from consumption brought on by a broken heart. This fate is so out of proportion to the crime-loving someone with all her heart - that readers questioned the moral code itself, and this challenge to the Confucian moral order made Pure Heart a cause célèbre in Hanoi.

Pure Heart's more complex moral message makes it, by Western standards, a better novel than Who Can Do It? In Hồ Bieu Chánh's novels there is always a villain-someone who is clearly bad and whose evil actions generate the conflictbut in Pure Heart there is no clear villain. The conflict in Pure Heart is internal and psychological: It occurs within the minds of the two main characters; it is not an external battle between good people and bad people. By presenting characters who are pushed and pulled by socially acceptable and unacceptable impulses, not characters who are all good or all bad, by making his novel more psychological, Hoàng Ngọc Phách produced a work more disturbing to readers than were Hồ Bieu Chánh's early novels.

Hồ Biêu Chánh and Hoàng Ngọc Phách wrote very different first novels in part because they preferred different French writers. Twelve of Hồ Biêu Chánh's sixty-four novels are modeled on Western works. His choices for these imitations suggest his reading preferences. The list includes Victor Hugo, Alexandre Dumas père, and a group of minor late nineteenth- early twentieth-century writers who are classified as realists by literary historians. It includes two writers, Hector Malot and Octave Mirbeau, who were associated with the naturalist writer Emile Zola.

Hoàng Ngọc Phách, on the other hand, preferred the champions of French romanticism. In a 1942 interview, he listed the French writers that he and his friends were reading around the time he wrote Pure Heart: "[W] preferred the writers and poets of the eighteenth and nineteenth century: Rousseau and Chateaubriand and the writers we called the 'top four': Lamartine, Hugo, Musset, and Vigny" (Lê Thanh 1942:102). Rousseau, Chateaubriand, Lamartine, and Musset all worked within the tradition of the bourgeois sentimental love novel, a tradition that began in England with Richardson's Clarissa and was promoted in France first by Abbé Prévost, who translated Clarissa and wrote Manon Lescaut (a popular novel in Hanoi), and then by Rousseau and his followers. In his 1942 interview, Hoàng Ngọc Phách explained that the "form" of Pure Heart, "the way of telling the story, the description of scenes-all this was according to French literature" (pp. 1034). By "French literature," Hoàng Ngọc Phách means the sentimental love novels, works like Chateaubriand's René, Rousseau's La Nouvelle Héloüse, Lamartine's Graziella, Musset's Confessions d'un enfant du siècle, and Alexandre Dumas fils' La dame aux camélias. 
The tradition of the European sentimental novel reached Vietnam both directly through those Vietnamese students who read these novels in French and indirectly via Vietnamese translations of Chinese mandarin duck and butterfly fiction, a type of popular story influenced by Lin Shu's popular translation of Dumas's La dame aux camélias. The writers of these stories were fond of the conventional symbols for lovers, the mandarin duck and the butterfly; hence the name for this type of fiction. Although later derided by the May Fourth critics as artistically inferior and ideologically backward, mandarin duck and butterfly stories were extremely popular in China, especially during the period 1910-30.

Characters in butterfly novels pass through stages of what Perry Link calls the "Romantic Route": "(1) Extraordinary Inborn Gifts, (2) Supersensitivity, (3) Falling in Love, (4) Cruel Fate, (5) Worry and Disease, and (6) Destruction" (1981:6478). These stages are evident in the works of Hsu Chen-ya (Vietnamese: Tủ Tram Á), one of the most popular authors of butterfly fiction. Two of his bestknown novels, Yu-li bun (Jade pear spirit, 1912) and Hsueb-bung lei-sbib (The sorrowful tale of a snow swan, 1915), are different versions of the same, sad love story. The main characters are a schoolteacher and a woman six years his senior. The love affair is doomed from the start because the woman, a widow with an eight-year-old son, could never remarry: Confucian morality demands that widows remain faithful to their dead husbands and devote themselves to their children.

This butterfly fiction was popular in Vietnam, especially in the North. A Vietnamese translation of Hsu Chen-ya's Hsueb bung lei shib (Vietnamese: Tuyết hồng lẹ sú) by Mai Khê appeared in the northern journal Nam Phong in 192324 , and at least eight novels by this champion of butterfly fiction were translated and published in Hanoi during the period 1925-32 (Rageau 1979). According to Thanh Lãng, "at first we translated only the old Chinese stories, especially stories

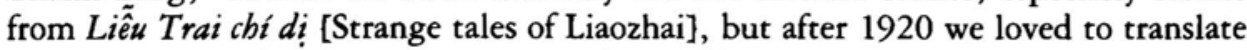
new stories recently written by authors influenced by the Western romantic movement, especially the novels of Tủ Trầ Á [Hsu Chen-ya]" (1967:468).

Hoàng Ngọc Phách's Pure Heart resembles the novels of Hsu Chen-ya, especially the Sorrowful Tale of the Snow Swan. Hoàng Ngọc Phách has his characters travel the same "Romantic Route" that is traveled by Hsu Chen-ya's characters. Both authors glorify and poeticize the negative feelings of sadness, despair, and loneliness brought on by a doomed love affair: Characters in both novels become martyrs who are willing to die for love. Hoàng Ngọc Phách finished writing Pure Heart three years before it was published in 1925, and so he could not have been influenced by Mai Khê's translation, but no doubt he read the Sorrowful Tale of the Snow Swan and other examples of Chinese butterfly fiction either in the original Chinese or in earlier translations. Hsu Chen-ya's debt to European models, particularly to Alexandre Dumas fils' La dame aux camélias, is, however, generally accepted; and so the similarities between his butterfly novels and Hoàng Ngọc Phách's Pure Heart may be a result of both authors reading the same Western works.

There is no evidence to suggest that Hồ Bieu Chánh and other early southern novelists were greatly influenced by French sentimental love novels and Chinese butterfly fiction. They were no doubt acquainted with these works but probably decided that southern readers, generally less concentrated among the petty bourgeoisie than were northern readers, would not react favorably to their intense romanticism. These works also ran counter to Hồ Biêu Chánh's personal interests. French sentimental novels concentrated so intensely on the internal feelings of characters afflicted with love that little room was left for the investigation of the external social world, the world that interested Hồ Bieu Chánh. He preferred the works of French realists and of the social romantic Victor Hugo. 
These preferences related to French literature are important to note and may partially explain some features of Hồ Biéu Chánh's novels-his refusal to ignore the social reality of his characters, for example, and his obvious sympathy for the unfortunate victims of corrupt and greedy landowners and officials. It is not possible, however, to be certain about cause and effect: Hồ Biêu Chánh's experience probably predisposed him to write novels of social criticism before he encountered works by French realists. One should not overemphasize Hồ Bieu Chánh's debt to French models, particularly when speaking of the 1912 version of Who Can Do It? Two Vietnamese literary critics make this mistake when they argue that Who Can Do It? is modeled on Paul Bourget's André Cornélis (1887) (Doãn Quốc Sỹ 1972:227; Thanh Lãng 1967:560). Bourget, a member of Emile Zola's circle, wrote realistic and naturalistic novels but is best known for his psychological novels-Le Disciple, Un Crime d' Amour, and André Cornélis. This last novel-part confessional tale, part detective story-is an account told in the first person of a youth who suspects that his stepfather killed his father. Paul Bourget was a popular author in Vietnam, and his André Cornélis may have persuaded Hồ Bieu Chánh to write a tale about an evil stepparent, but the two novels differ too much to argue that Hồ Bieu Chánh modeled his first novel on this French work. André Cornélis is a psychological novel that explores the effect of suspicion and vengeance on a young man's mind; Who Can Do It? is a moral tale about the wickedness of greed and the value of righteousness. The fact that Hồ Biêu Chánh does not include Who Can Do It? on his list of novels modeled on French works is further evidence against the modeling hypothesis (Nguyễn Khuê 1974:160).

More research needs to be done on the influence of butterfly novels and other forms of late Ch'ing Chinese fiction on Hồ Bieu Chánh and his circle. It appears the influence was slight. The Vietnamese translation of Sorrowful Tale of a Snow Swan was serialized in a northern journal; translations of Hsu Chen-ya's novels were published in Hanoi, not in the South (see Rageau 1979). Southerners preferred more traditional Chinese stories, especially the well-known long Chinese historical romances such as The Three Kingdoms and The Water Margin, and short stories from collections such as Chin-ku ch'i-kuan (Marvelous stories, old and new) and Liao-chai chib-i (Strange tales of Liaozhai). These, were the Chinese works that southern scholars first translated when knowledge of Quố ngü became widespread at the beginning of the twentieth century (Bùi Đúc Tiṇh 1974:172; Bằng Giang 1992:234-74).

\section{Three Qther Southern Writers: Hồ Bieu Chánh's Predecessors}

The evidence suggests that when Hồ Biêu Chánh wrote the first version of his first novel he was inspired more by works by fellow southerners than by French or Chinese novels. Until recently these works have been completely ignored by literary historians, but their existence proves that southerners were writing prose narratives using modern novelistic techniques at least fifteen years before Hoàng Ngọc Phách's Pure Heart was published in Hanoi. In an unpublished autobiography analyzed by (Nguyền Khuê (1974:32,306-7), Hồ Biêu Chánh explains that, after he finished Story of Secret Love, he was strongly influenced by three prose narratives written by southerners: (Nguyên Trọng Quản's "Truyện Thây Lazaro Phiền" (The story of Lazaro Phiền) (1887), Trủỏng Duy Toản's Phan Yên ngoai sủ (An unofficial history of Phan Yên) (1910), and Trấn Chánh Chiếu's Hoàng Tồ Anh bàm oan (The unjust suffering of Hoàng Tô Anh) (1910). These three works are very different, but they are all 


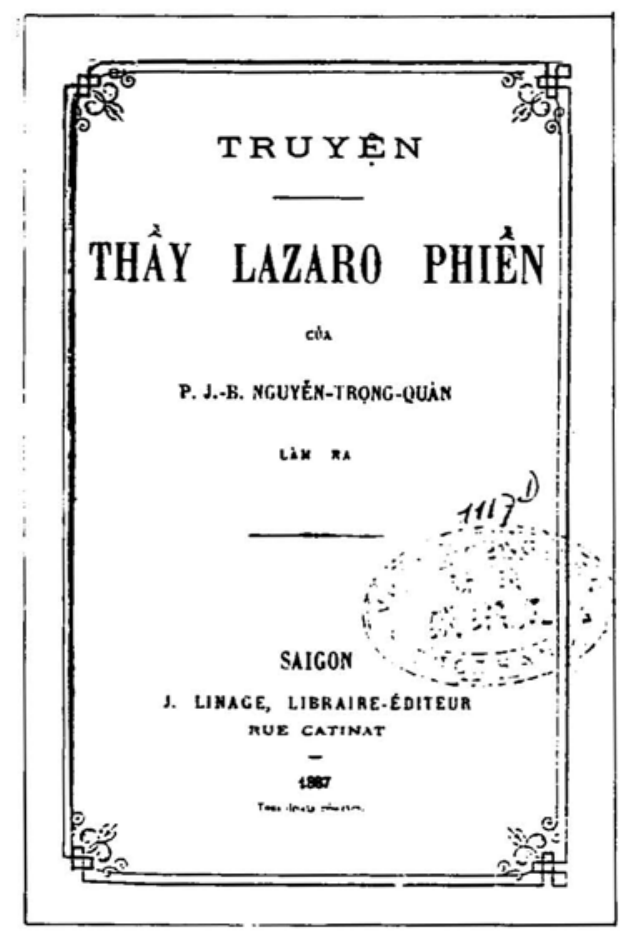

Illustration 3. The title page of "The Story of Lazaro Phiền" (1887), the remarkably modern short story by Nguyến Trọng Quản that impressed Hồ Biêu Chánh.

set in the southern Six Provinces and all feature ordinary southerners as characters. Hồ Biè Chánh specifies that his reading of these works, particularly The Unjust Suffering of Hoàng Tô Anb, influenced him greatly and convinced him to move from verse to prose. We will look at these works briefly to make clear that while Hồ Bieu Chánh was the most prolific and most enduring southern novelist, he was not the first southerner to write a long narrative in prose with a local setting and ordinary people as characters. He was a member of a community of southern writers and newspaper editors who, as the verse narrative declined, began to experiment with the new genre of the novel.

The earliest work, "The Story of Lazaro Phiền" (1887) (illustration 3), is a short story, not a novel: It covers eleven pages when reprinted in a modern journal. Its author, Nguyền Trọng Quản, was a Catholic who studied abroad at the Lycée D'Alger in Algeria and later became the principal of a primary school. He was also an artist, and his illustrations appear, in Trủong Duy Toản's An Unofficial History of Phan Yên and Trân Chánh Chiếu's The Unjust Suffering of Hoàng Tố Anh (Nguyên Văn Trung 1987:23-26).

His story is a skillfully constructed account of a man (Lazaro), originally an interpreter for the French colonial government, who kills his wife and best friend because he wrongly believes that they have been lovers. The villain is a Vietnamese woman, the wife of a Frenchman, whose advances Lazaro once spurned: She provides false evidence and dupes poor Lazaro. After he commits his terrible crimes, but before he learns that his wife and friend are innocent, Lazaro is wracked by guilt. His later realization that he is guilty not only of murder but of the murder of 
innocents becomes the final turn of the screw that drives him to despair and death.

The story has many modern features. It is a framed narrative: Lazaro's story, his confession, is told to a man he meets on a boat traveling to Bà Rịa. This man becomes the narrator who retells Lazaro's story for the reader. In other words the traditional way of naturalizing a narrative by introducing it as a retelling of a tale found in an ancient book has been abandoned. The first-person point of view, the unhappy ending, the fairly descriptive and colloquial style, and the Christian content are other features that would have made this an unusual tale when it arrived on the literary scene in Cochinchina in the late 1880s. No doubt its radical modernity and Christian themes prevented it from being enthusiastically received in 1887. Nguyên Văn Trung explains that its title alone, which suggests a tale designed not for entertainment but for religious instruction, would have turned away many Vietnamese readers (1987:25).

How did this tale influence Hồ Biêu Chánh? We can only speculate, of course, but by comparing this tale with Hồ Biêu Chánh's first novel, some observations can be made. First, in "The Story of Lazaro Phiền," Nguyễn Trọng Quản clearly abandons the scholar-beauty tradition much more completely than Hô Bieu Chánh was prepared to abandon it when he set out in 1912 to write his first version of Who Can Do It? A Buddhist and a traditional Confucian moralist, Hồ Bieu Chánh was not likely to start turning out tales based on Christian notions of guilt and the power of confession. Hồ Bieu Chánh's first novel is much more traditional in plot and theme: It describes the trials and tribulations of a young scholar and a virtuous girl and ends happily in a way that reinforces the traditional Confucian virtues. "The Story of Lazaro Phiền," in contrast, describes not the trials and tribulations of young lovers but the progressive mental and physical deterioration of a man wracked by guilt.

Probably Nguyển Trọng Quản's work, and those by Trủỏng Duy Toản and Trần Chánh Chiêu, affected Hồ Biêu Chánh most by convincing him that one can produce stories in prose with local settings and with ordinary southern Vietnamese as leading characters. Perhaps, too, Nguyển Trọng Quản's short story suggested to Hồ Bieu Chánh that forbidden passions and crimes such as revenge and murder were suitable topics for narratives. Revenge and acts of violence were common in the knight-errant tradition but less common in scholar-beauty stories, which favored such more genteel transgressions as cheating on examinations and in poetry contests. Revenge, however, is a consuming passion of leading characters in both "The Story of Lazaro Phiên" and Who Can Do It? Murder by poison occurs in both works. There also are some similarities between "The Story of Lazaro Phiền" and Story of Secret Love: For example, in both works a female villain forges a letter and uses it to spur a false accusation of infidelity against her rival.

Nguyến Trọng Quản's quite simple and colloquial style also probably inspired Hồ Bieu Chánh. Although the story has little extended description of scene or character, there is some description, and it is particular and realistic, not at all like the poetic cliches favored by the composers of verse narratives.

The next two works that Hồ Bieu Chánh says influenced him were written by men who were active in anti-French political movements, particularly in a program called the Duy Tân Hội (Reformation Society) (Tran Huy Liệu et al. 1958; Marr 1971). This society was formed primarily by the efforts of Phan Bội Châu, a Vietnamese patriot whose activities form a bridge connecting the Cần Vủỏng (Loyalty to the King) Movement of the mid-1890s with the struggle led by Hố Chí Minh that began in the 1930s. The leaders of the Reformation Society, who were inspired by the Chinese reformers K'ang Yu-wei and Liang Ch'i-ch'ao, originally wanted to find 


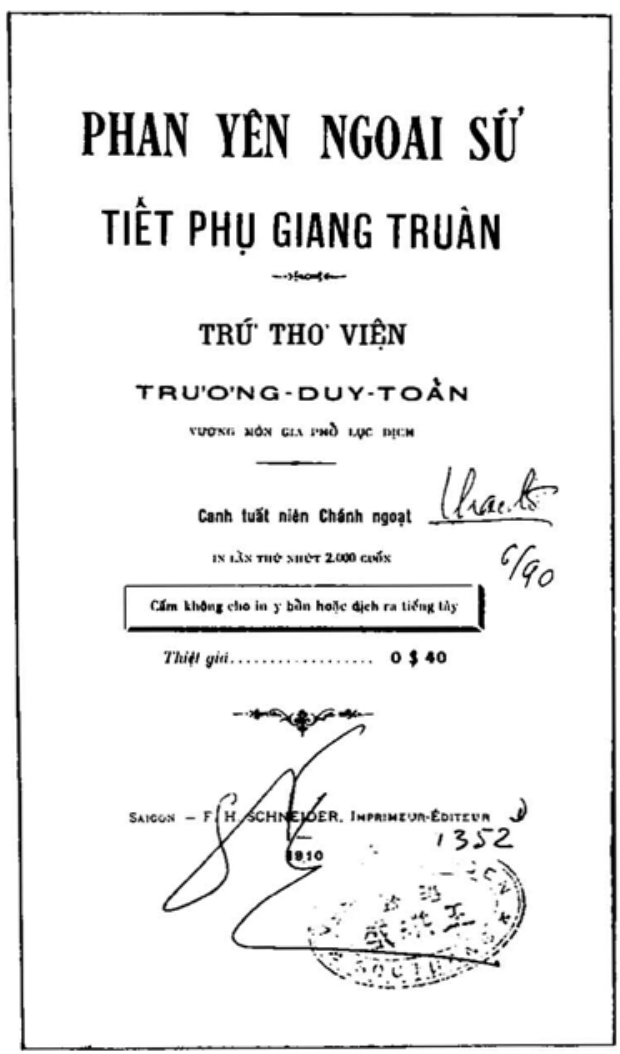

Illustration 4. The title page of An Unofficial History of Phan Yên:

Trials of a Virtuous Widow (1910) by Trủong Duy Toản.

a member of the royal family who would be acceptable as a titular leader. They decided that Prince Củỏng Đê, a direct descendant of Gia Long, the first Nguyên emperor of Vietnam, was the best person for this role. When Prince Củong Đê, went to Europe in 1913 to enlist support for anti-French efforts, he took with him a man fluent in French to act as interpreter (Tùng Lâm 1957:80). When they were in England, the Prince sent his interpreter on an errand to France, where he was arrested and thrown into the Prison de la Santé in Paris. The French deported him to Vietnam in 1916, where he became a well-known newspaper editor and composer of a new kind of musical drama called "cãi lüong" (reform opera) (Hoài Anh 1988:24-25).

This man was Trủong Duy Toan, who before he left for Europe had written one of the three works that Hồ Bieu Chánh credits with encouraging him to write his first novel. The work by Trủong Duy Toản that caught Hồ Bieu Chánh's attention was a forty-eight page narrative called Phan Yên ngoai sü-Tiết phu gian truân (An unofficial history of Phan Yên-the trials of a virtuous widow) (illustration 4), published in 1910. Phan Yên is not the virtuous widow's name; it is the name of a place - the former name for Gia-đinh, a region bordering Saigon. The story, rooted firmly in the knight-errant/scholar-beauty tradition, concerns a man who saves a young woman from brigands and then departs with some followers to perform good deeds. Both hero and heroine suffer various trials and tribulations but are eventually joyfully reunited. 
This story is so traditional that Hoài Anh does not use the usual Vietnamese term for novel (tiêu thuyết) when he refers to it, classifying it instead as a truyện chi (1988:75), a term he uses for works that resemble such Chinese historical romances as The Three Kingdoms more than they resemble modern novels written under the influence of Western models. This work was innovative in one respect, however. Although it takes place at the time of the Tây Son rebellion-the last quarter of the eighteenth century-Trủong Duy Toan clearly means to comment on the contemporary political situation in Vietnam, and so the work has the quality of a roman à clef. This quality gives the work current relevance, a feature commonly used to distinguish a novel from a romance.

The Tây Son rebellion was a revolt against the Nguyền rulers in the South, who were already weakened by a civil war with the Trịnh rulers in the North. The Tây Son forces defeated the Trịnh faction and subdued the Nguyên rulers for a time, but eventually Nguyên Ańh regained control of the country and became Emperor Gia Long in 1802. Toward the end of An Unofficial History of Phan Yên, the hero becomes the leader of a band that collects funds for Nguyên Ańh, who is "repairing ships and preparing weapons in order to eradicate the gang of Nhac, Huẹ." "Nhacc" and "Huệ" are the names of two of the three brothers who led the Tây Son rebellion, but Vietnamese readers would understand all references to the Tây Son rebels as indicating the French as well. The identification is encouraged by the word "Tây" in "T̂ay Sỏn." "Tây" means "west" and is used by Vietnamese to refer to the French (Hòai Anh 1988:83). The fact that An Unofficial History of Phan Yên makes reference to contemporary affairs could lead one to call this work a novel, but it should be considered a transitional work, with some traditional truyện $c b i$ elements and some more modern novelistic features.

Trủỏng Duy Toản's An Unofficial History of Phan Yên probably assisted Hồ Biêu Chánh by revealing to him that the knight-errant and scholar-beauty traditions could be combined in Vietnamese prose as well as in verse. The hero, a knight-errant as well as a scholar, is involved in exciting events that test his physical prowess. It seems likely that Hồ Bieu Chánh was impressed by the adventure story elements of Trủong Duy Toản's work: There are last-minute escapes, battles with kidnapers, shipwrecks at sea, etc. The love story predominates in Hồ Bieu Chánh's first novel, Who Can Do It? , although it contains some elements of the adventure story, but his next two novels, Cbúa tàu Kim Qui (The ship captain of Kim Qui) and Cay đáng mùi đờ (The bitterness of life), are primarily adventure stories, although the former has some love-story elements. Hồ Bieu Chánh modeled these works on Compte de Monte-Cristo and Sans famille, and so we can assume that Hồ Biêu Chánh's reading of French novels pushed him toward the adventure story. There was precedent, of course, for mixing love and adventure before An Unofficial History of Phan Yên or French novels arrived on the scene. As we have pointed out, Kim Vân Kiều, the scholar-beauty story in verse that most influenced Vietnam's early novelists, is as much a tale of harrowing adventures as of romantic love; and knight-errant stories were, essentially, stories of adventure. But Trủong Duy Toan demonstrated for Hồ Biêu Chánh how to mix these elements in Vietnamese prose.

The author of the third work that Hồ Biè Chánh mentions as an important influence was, like Trủong Duy, Toản, active in anti-French political movements. His name was Trần Chánh Chiêu, but he was also known as Gilbert Chiếu, Trần Thiên Trung, and Trần Nhụ̂t Thăng. His novel, the work that Hồ Biè Chánh says convinced him to abandon verse for prose narrative, was The Unjust Suffering of Hoàng TốAnh (1910) (illustration 5). An important member of Phan Bội Châu's Reformation Society, Trân Chánh Chiêu worked in a variety of capacities to promote the moral, 

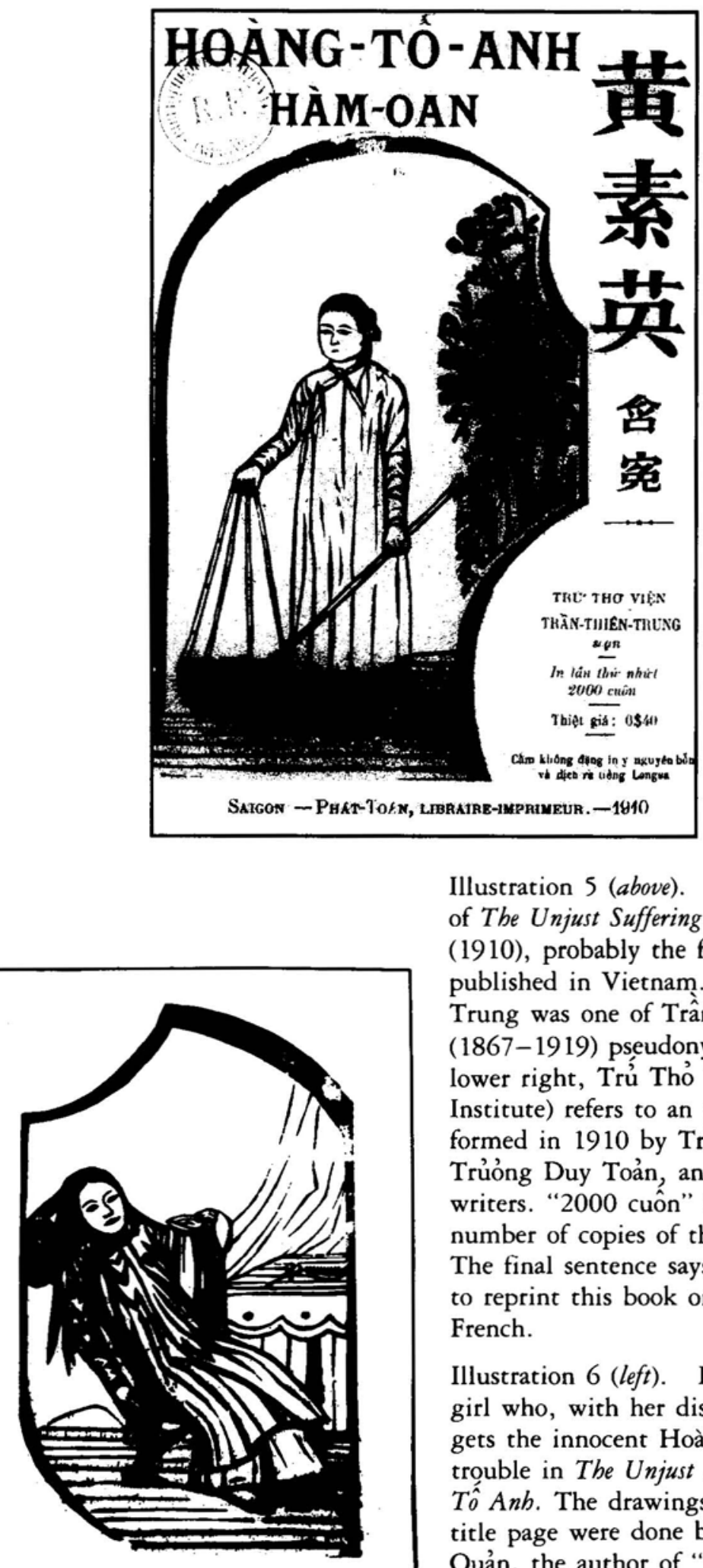

Illustration 5 (above). The title page of The Unjust Suffering of Hoàng Tô Anb (1910), probably the first novel published in Vietnam. Trần Thiên Trung was one of Trân Chánh Chiêu's (1867-1919) pseudonyms. At the lower right, Trú Tho Viện (Writers' Institute) refers to an association formed in 1910 by Trần Chánh Chiếu, Trủong Duy Toản, and other southern writers. "2000 cuôn" indicates the number of copies of this first printing. The final sentence says it is forbidden to reprint this book or translate it into French.

Illustration 6 (left). Kim Tiên, the girl who, with her dissolute boyfriend, gets the innocent Hoàng Tô Anh in trouble in The Unjust Suffering of Hoàng Tô Anh. The drawings on this and the title page were done by Nguyen Trong Quan, the author of "The Story of Lazaro Phiền." 
political, and economic reform of his country. Born in Rạch gía, Hà Tiên Provincethe southernmost province of Vietnam - into a wealthy family, he studied at the College D'Adran in Saigon and later became an interpreter, hotel owner, newspaper editor, founder of an industrial corporation, and a key supporter of Phan Bội Châu's resistance activities. His status as a dual citizen of France and Vietnam enabled him to operate more boldly than other supporters of Phan Bội Châu's (Thái Văn Kièm 1960; Trần Huy Liẹu et al. 1958; Hoài Anh 1988).

When French authorities clamped down on the activities of the Reformation Society, Trần Chánh Chiếu apparently decided he could continue to help achieve the aims of the Reformation Society by writing novels. The Unjust Suffering of Hoàng Tố Anb does not strike a modern Western reader as in any way a political book. Like the novels by Hồ Bièu Chánh, Trần Chánh Chiéu's narrative is primarily a moral, not a political, story. For men like Trần Chánh Chiêu and other supporters of the Reformation Society, however-for Vietnamese who believed that the moral character and knowledge of the people had to be improved before independence from the French could be achieved-moral reform was a type of political action. Like the Chinese reformers $\mathrm{K}$ 'ang Yu-wei and Liang Ch'i-ch'ao, important advisers to the Vietnamese leaders of the Reformation Society, Trần Chánh Chiếu was convinced that the novel could be an instrument of moral reform.

The Unjust Suffering of Hoàng Tố Anb is certainly a moral tale. Set in Saigon, it is the story of a poor young girl, a seller of betel leaves, who is accidentally struck by a carriage driven by a wealthy man and his son. The wealthy man takes the girl to his house, ostensibly to allow her to recuperate but actually to pursue his (and, it turns out, his son's) lascivious designs on the attractive street peddler. As a result of her friendship with the wealthy man's daughter, Kim Tiên (illustration 6), who is secretly seeing and sleeping with a dissolute youth, Hoàng Tố Anh is involved in an incident that causes her the unjust suffering of the title. The youth, a compulsive gambler who is in debt to some Indian usurers, persuades Kim Tiên to forge one of her father's bank withdrawal forms. When Kim Tiên asks Hoàng Tố Anh to take the form to the bank and get the money, she innocently complies.

After Kim Tiên's brother and then her father attempt to rape Hoàng Tố Anh, she flees. When the money is discovered missing, the police arrest her. Eventually, Hoàng Tố Anh's innocence is established, the wrongdoers are punished, and she marries a poor but virtuous boy from her neighborhood. In the ending, something that had been hinted at earlier is fully revealed: Hoàng Tô Anh is actually the wealthy man's wife's daughter, the product of a youthful liaison that the family had successfully kept secret. A rich uncle, the husband of the sister of Hoàng Tố Anh's real mother, surfaces and buys Hoàng Tố Anh and her husband a fine house.

The Unjust Suffering of Hoàng Tô Anh, which contains about 20,000 words and is divided into fifteen chapters, exhibits many vestiges of traditional narration: chapter headings, usually in parallel syntax, announcing key events in the chapter; formulaic language to announce transitions ("Now it, will be told how Ba Xóm took the blank withdrawal form . . ." [Trần Chánh Chiếu 1910:25]); unindividualized characters that stand for virtues and vices; and an ending that reinforces an explicitly stated moral.

This last feature-the ending - is perhaps the most troublesome for a modern reader. Trần Chánh Chiếu makes his traditional theme explicit by using a saying from Minb Tâm bưu giám (Precious mirror of the heart), a collection of wise sayings by Confucius, Mencius, and other Chinese sages, as the title of his last chapter. The saying, "Kindness and cruelty both have consequences," was well known and 
expressed a moral principle that all the early southern novelists wished to inculcate in their readers. Hồ Bieu Chánh, for example, uses the same saying as a coda for his second novel, the Ship Captain of Kim Qui. This traditional theme, however, led to some problems for southern novelists attempting to write a modern novel. It necessitated a happy ending, or hậu, in which the kind receive their reward and the cruel their punishment. To make sure that readers do not miss the causal relation between immorality and punishment, Trần Chánh Chiéu employs parenthetical asides. When the dissolute youth's misdeeds are exposed and he slits his throat, the author includes this editorial note in parentheses: "Thus ends the life of a dishonest youth!" And after Kim Tiên dies as a result of taking medicine to induce an abortion, there appears a similar comment: "Thus ends the life of a lewd girl!"

This quick tidying up, the hurried disbursal of rewards and punishments, was common in Vietnamese verse narratives. In Luc Vân Tiên, Nguyê̂n Đình Chiêu dispatches his evil characters by having some devoured by tigers and others swallowed whole by a whale. Vietnamese readers accepted these contrived and hurried endings in verse, a less realistic and more concise medium, and they accepted them for a while in these pioneering prose novels. We will see, however, that when Hồ Biê Chánh revised his first novel, he altered his original ending to make it less contrived, more realistic - a fact that suggests that he realized that a quick and excessively tidy distribution of rewards and punishments was not an appropriate ending for a modern novel.

Besides its setting in Vietnam and its ordinary language, what else might Hồ Biêu Chánh have found inspiring in Trần Chánh Chiếu's narrative? What would have prompted him to specifically mention this work as the inspiration for his first novel? Probably Hồ Bieu Chánh was impressed by Trần Chánh Chiếu's sharply critical portraits of southerners and their families, portraits that reveal how those in influential positions betray the public trust and use their wealth and power to satisfy their own selfish desires. Hồ Biêu Chánh filled his novels with similar portraits. No doubt, his primary source for these portraits was his own observation of life in the Six Provinces, observation facilitated by his own position in the colonial bureaucracy, but it seems clear that Trân Chánh Chiếu's novel assisted him greatly by revealing the possibilities that the novel afforded for social criticism.

\section{From Straight-line Narration to Modern Novel}

When Hồ Bieu Chánh wrote the 1912 version of Who Can Do It? he was obviously feeling his way, learning a completely new way of telling stories. Before 1912 the only original story he had published was a verse narrative-Story of Secret Love. Sensing that readers could be "moved" more easily with prose than with verse, he was determined to try to write a prose narrative. Later he became aware of his first novel's shortcomings, rewrote it, and published a second version in 1922. By comparing the 1912 and 1922 versions, one sees how Hồ Bieu Chánh refined his prose style-how he moved away from the "straight-line narration" (tü thuât theo düning thäng) common in the Sino-Vietnamese tradition and began to employ methods of exposition similar to those used by Western novelists.

Pham Quỳnh, editor of the northern journal Nam Phong (Southern ethos), describes this "straight-line narration" in the first critical study in Vietnamese of the modern novel (1921). In this straight-line method, which, Pham Quỳnh argues, was favored by traditional Chinese and Vietnamese writers, the author puts down events as if 
he were recording history or making entries in a family register; there is little pausing to describe scenes or feelings. If background information-the prior life of a character, for example-is needed, the main story is interrupted and the author tells another story from beginning to end before returning to the main narrative. Western novelists, says Pham Quỳnh, use a more indirect and spontaneous approach to narrative exposition. When background information must be included, they interweave it with the main narrative; they do not supply it in one long passage. They also include more description and dialogue.

Possibly Hồ Bièu Chánh read Phạm Quỳnh's analysis. Or perhaps he came to the same conclusions from his reading of Western novels and by writing novels modeled on French works. In any event, close study of Hồ Bieu Chánh's revision of his first novel reveals that he was sensitive to the points mentioned by Pham Quỳnh: In his revision he moves away from straight-line narration toward the narrative method favored by Western novelists as Phạm Quỳnh describes it.

In his revision, Hồ Bieu Chánh does not alter the plot in any significant way: The major events occur in the same order in both versions. He does, however, alter the ending to make it more realistic. To end his first version, Hồ Bièu Chánh has a visitor return to Cà Mau five years later and encounter a perfectly symmetrical tableau. In front of a large house standing between two smaller houses are eight people: the hero and heroine, the heroine's father and grandfather, the couple who assisted the hero and heroine, and four children - two for each of the happy couples. In addition, we learn that the hero and his friend have become the richest men in Cà Mau. The 1922 version also ends happily but less symmetrically: The hero and heroine settle contentedly in Cà Mau and the man and woman who helped them return to Vĩnh Long, but there is no mention of children and nothing is said about the hero and his friend becoming the richest men in Cà Mau.

Hồ Biè Chánh makes other changes to modernize his story. He compresses the twenty-seven short sections of the 1912 version into six chapters averaging about thirty pages each. In place of the traditional headings that announced the topic of the sections in his first version, he places a simple roman numeral. He also removes the clumsy intrusions by the narrator that in his first version announced transitions in the plot. The 1922 version is also about 15,000 words longer than the first. Hồ Bieu Chánh uses the additional words to provide more information to clarify events and more description and dialogue to dramatize scenes. These changes make his revised version read more like a modern novel. In the 1912 version, for example, the heroine makes two visits to the hero's room one night. On the first visit, she simply asks whether he has recovered from a stomach ailment. On the second, she pours out her entire life story in a long monologue. In the 1922 version, however, the heroine makes no second visit to the hero's room: The same background information is presented in dramatic conversations between the heroine's father and stepmother, between the heroine and her father, and between the heroine and hero.

By not having the heroine make a second visit alone to the hero's room, Hồ Bieu Chánh also improves the plausibility of the novel. Even a short visit to inquire about the hero's health would strain plausibility; a second long visit to pour out one's life story would represent bizarre behavior in late nineteenth-century Vietnam. In the revision, the heroine joins the hero alone in his room only after her plight has become truly desperate and she has followed him to another town. The hero tells the hotel owner that the heroine is his younger sister. In his hotel room that night, hero and heroine agree to elope but only after the hero has asked the heroine some hard questions about how she intends to revenge her mother's death. It is 
clear that the hero is weighing the dangers of running off with the daughter of a powerful official.

The effect of these changes is to make the actions of the novel not only more plausible but also more psychological. In the 1912 version the hero and heroine appear to act with very little reflection. In this respect, they resemble the hero and heroine of Story of Secret Love. In the 1922 revision, Hô Bieu Chánh uses description and dialogue to reveal the inner thoughts of his characters.

\section{Conclusion: Regional Differences}

Because Cochinchina had been a colony of France since 1867, southerners were exposed to French culture earlier and more intensely than Vietnamese living in the protectorates of Annam (central Vietnam) and Tonkin (north Vietnam). This exposure was facilitated by the more rapid changes in education that occurred in the South. In Cochinchina, Franco-Vietnamese education in French and Quî́ ng $\vec{u}$ replaced traditional education in Chinese based on the Confucian classics earlier and more thoroughly than was the case in the protectorates. When these differences between the regions are understood, the question becomes not why the novel emerged first in Cochinchina but why literary historians have failed to acknowledge the achievements of Hồ Bieu Chánh and his predecessors. There are several reasons, lack of access to their works being one. Book editions of the works of Hồ Bieu Chánh's three acknowledged predecessors and his own early works have been tucked away in private libraries in Cochinchina out of reach of scholars. If these early works were originally serialized in southern newspapers, these versions have also remained inaccessible to scholars-buried in unindexed and incomplete collections of Nông Cồ Mín Đàm, Lục Tĩnh Tân Văn, and other southern newspapers. Writing in 1941, Vũ Ngọc Phan says that he has heard that Hồ Biè Chánh wrote six novels before 1928, including one called Ai làm düọc, but, he says, copies of these earlier works haven't been available in northern bookstores for a long time (Vũ Ngọc Phan 1941:360). Perhaps if he had found these earlier works, Vũ Ngọc Phan would not have argued, as he does (1941:158), that the novel began in the North. Locating key texts remains a problem for anyone studying southern literature, as the present authors have learned from experience and from talking with Vietnamese scholars during a recent trip to Vietnam.

Regional prejudice or, perhaps more accurately, prejudice against popular vernacular literature is another explanation for the neglect of Vietnam's early southern novelists. Pham Thế Ngũ, as we stated earlier, disliked much southern literature because it was composed in the rhythms and diction of everyday southern speech. Northerners preferred (and many still prefer) a literature that is more distanced from ordinary speech and that contains fewer regional expressions. These attitudes are changing, and new appreciation of the contributions of southerners is emerging. More readers are beginning to consider the representation in print of regional speech an endearing stylistic feature-a literary achievement, not an artistic failure.

The fact that southerners have not been interested in writing literary criticism is another explanation for the neglect of southern novelists. As Nguyên Văn Trung points out, these southern novelists have been forgotten in part because southerners have themselves forgotten them (1987:17). Southerners have left the writing of literary history to northerners, who either did not know the works discussed here existed or, if they had encountered one, most likely a novel by Hồ Bieu Chánh, dismissed it as subliterary. 
If the novel emerged first in Cochinchina, why didn't the first southern novels shock readers as much as Hoàng Ngọc Phách's Pure Heart shocked readers in the North? Why is the story of the novel's emergence in the North one of violent disruption of traditional values whereas its arrival in the South is marked by continuity? One might think that such works as Trần Chánh Chiếu's The Unjust Suffering of Hoàng Tố Anb and Hồ Biêu Chánh's Who Can Do It? , works that deal frankly with such passions as sexual desire, would have provoked more controversy than Pure Heart. Though Tố Tâm, the heroine of Pure Heart, was in many ways a liberated and modern woman (compared to the social norm of Hanoi in 1925), she and her lover do not, as do Hồ Biêu Chánh's characters, indulge in premarital sex. Their relationship is quite platonic and is based, as the hero explains, on mutual respect, not physical attraction (Hoàng Ngọc Phách 1925:57). So why did their behavior shock readers while the behavior of the hero and heroine in Who Can Do It? was accepted without comment?

There are several explanations for the different reactions to Pure Heart and these first southern novels. First, there is nothing prurient about The Unjust Suffering of Hoàng Tô Anb and Who Can Do It?; they contain nothing, for example, even remotely approaching an explicit description of sexual intercourse. In Who Can Do It? , for example, the hero and heroine simply begin living with each other because the heroine has no place to go. Another early southern novelist named Lê Hoằng Mủu, a contemporary of Trần Chánh Chiêu and Hồ Biêu Chánh, dealt with sexual matters more persistently and less circumspectly and was accused of writing pornography (Nguyen Văn Trung 1987:81-101; Hoài Anh 1988:89-97). Unlike Lê Hoâng Mủu, neither Trần Chánh Chiếu nor Hồ Biêu Chánh moved beyond what they knew would be socially acceptable.

The circulation of such transitional works as Hồ Biể Chánh's Story of Secret Love and his first version of Who Can Do It? is another explanation for the calm reception of the novel in the South. As we have attempted to demonstrate, this new genre, the novel, did not burst suddenly on the literary scene in Cochinchina. In Story of Secret Love and the 1912 version of Who Can Do It? the evolutionary process from verse narrative to modern novel was revealed; there were few missing links. In contrast, Pure Heart arrived on the Hanoi literary scene with little advance warning. Transitional works resembling Story of Secret Love and the $1912 \mathrm{Wbo}$ Can Do It? did appear in the North-for example, Trọng Khiêm's Kim Anb lệ su (1924) (The sorrowful tale of Kim Anh) and Nhât Linh's Nho phong (1925) (Confucian manners)-but they appeared around the same time or after, not before, Pure Heart appeared.

The fact that these southern transitional works, these texts that departed from the traditional verse narrative and began to resemble novels, all advocated Confucian moral principles also explains their calm recception. Except for Nguyến Trọng Quản's short story, "The Story of Lazaro Phiền," a work too Christian to provoke much attention, all the southern works that we have discussed preserved the traditional bâu, or happy ending, in which the good are rewarded and the bad get their just deserts. This traditional ending was the device that delivered the moral message: Obey the traditional Confucian virtues of loyalty, filial piety, and human righteousness (nhân nghia) or suffer the consequences. Retaining this bậu gave southern writers a license to depict passions, particularly sexual desire, quite frankly - much more frankly than it was treated in Pure Heart. Characters could lapse into premarital sex, clearly a violation of traditional Confucian morality, and conservative readers would not object because the novel's hậu reaffirmed the overall Confucian system.

In Who Can Do It?, however, the bâu rewards the heroine, who has lived with a man before marriage, creating the possibility of a confused moral message. Apparently 
recognizing this problem, Hồ Biêu Chánh added a scene to his 1922 revision in which the heroine, overcome with shame for being not chaste (bât trinb) and not filially pious (bất hiếu), plans to commit suicide. The hero finds her partially finished suicide note and convinces her that she had to violate these Confucian virtues in order to revenge her mother's death. This revenge theme receives much greater emphasis throughout the revised version than it does in the 1912 version. It seems clear that Hồ Biè Chánh strengthened the revenge theme to emphasize the extenuating circumstances that justify the heroine's transgression of the Confucian moral code.

Why didn't southerners make their early novels vehicles to challenge the Confucian moral order? Why did they leave this challenge to northerners, first to Hoàng Ngọc Phách and then later to the writers of the Tự Lụ̂c Văn Đòan (Self-Strength Literary Group)? ${ }^{3}$ According to Nguyền Văn Trung, the South's greater reluctance to abandon traditional Confucian morality stems from Cochinchina's peculiar status as a colony exposed to a policy that stressed assimilation to Western cultural values. Because for Vietnamese in Cochinchina the danger of "mât gốc," or cultural deracination, loomed larger than it did for northerners, southerners clung more tightly to traditional morality. Nguyền Văn Trung also believes that the South's history as a frontier region, a land that Vietnamese in their "Southern Movement" (Nam Tiến) did not completely wrest from the Chàm and the Cambodians until the end of the eighteenth century, helps explain the South's greater devotion to Confucianism. As settlers in a new land, the forefathers of these early southern novelists were freer to choose what cultural baggage to keep and what to abandon. They decided not to jettison the old moral system. According to the principle, "More freely chosen, more highly valued," this choice gave Confucianism in the South a new lease on life.

Another explanation for the more traditional thematic content of the first novels in the South lies in the different readerships in the two regions. Hoàng Ngọc Phách's readers were young intellectuals in Hanoi, members of a small but growing petty bourgeoisie class who knew Quî́c ngü and would appreciate a novel that resembled French sentimental novels like Lamartine's Graziella and Alexandre Dumas fils' La Dame aux camélias - works that they were encountering as part of their education in Franco-Vietnamese schools. Pure Heart originally appeared in the school newspaper of the Hanoi Teacher's College. Tố Tâm and Đạm Thủy, the hero and heroine of Pure Heart, are refined and literary: they both have pen names, write poetry, quote lines from Lamartine's "Le Lac," and discuss French novels. This is a completely different world from the world of Hồ Bieu Chánh's couples in Story of Secret Love and Who Can Do It? Tố Tâm and Đạm Thủy would consider the sexual lapses of Hồ Biêu Chánh's characters to be vulgar-violations of the aesthetics of love to which they are committed.

Hồ Bieu Chánh, on the other hand, was writing for a more varied and larger readership in the South, where literacy in Quốc ng $\tilde{u}$ was more widespread. Most of his first novels first appeared in serial form in southern newspapers, and some were serialized in advertising pamphlets issued by a company selling traditional medicine. Hồ Biêu Chánh was sensitive to the reactions of his readers, as comments in his autobiography attest: He knew that for them sex out of wedlock, though wrong, was a fact of village life; and he knew that for them "luân thüong" - the Confucian

${ }^{3}$ This group of writers, of whom the most prominent was Nhất Linh, wrote novels that attacked Confucian morality. For a good example, see Nhât Linh's Đoạn Tuyệt (Breaking away) (1934). 
bonds and virtues-were the bedrock of their world-view. And so he gave them, again and again in over sixty novels, the moral messages he knew they expected.

Hồ Bieu Chánh's stubborn refusal to abandon traditional Confucian themes has unfortunately prevented literary historians from appreciating his technical achievements in the novel, although they are considerable. He and his circle took the traditional verse narrative and transformed it into the modern novel. It is too early for a final assessment, too early to determine, for example, whether the South or the North deserves more credit for bringing about the transition from a traditional literary culture based on chü nôm, the logographic characters, to a modern one based on Quố ngư, the new roman script. In 1944 Ung Ngọc Ky summarized the literary achievements of southerners in this way: "First the wave of literature in Chinese and demotic characters moved from the North to the South; now the wave of Quố ngü moves in the opposite direction-from the South to the North" (quoted by Bang Giang 1922:24). To determine the truth of this bold claim we need to assess achievements in translation, journalism, poetry, drama, and lexicography. In the realm of the novel, however, it is clear that southerners made a major contribution, one that must be considered by literary historians of the future.

\section{List of References}

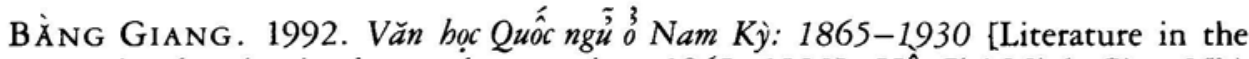
national script in the southern region: 1865-1930]. Hô Chí Minh City: Nhà Xuất Bản Trè, 1992.

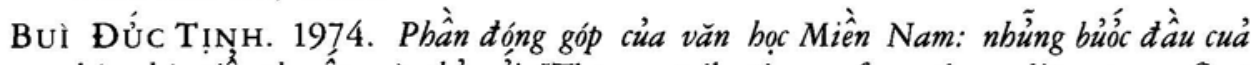
báo chi, tièu thuyêt, và thỏ mói [The contributions of southern literature: first steps in journalism, the novel, and new poetry]. Saigon: Lủa Thiêng.

CAO Thị Nhu'-QuỲnh and John C. SChafer. 1988. "From Verse Narrative to Novel: The Development of Prose Fiction in Vietnam." The Journal of Asian Studies 47:756-77.

Crawford, William. 1972. "Beyond the Garden Wall: A Critical Study of Three Ts'ai-tzu cbia-jen Novels." Ph.D. diss., Indiana University.

Davis, LeNNARD J. 1983. Factual Fictions: The Origins of the English Novel. New York: Columbia University Press.

DeFrancis, John. 1977. Colonialism and Language Policy in Vietnam. The Hague: Mouton.

DoÃN QUốc SỸ. 1972. Văn học và tiểu thuyết [Literature and the novel]. Saigon: N.p.

Henry, ERIC. 1984. "On the Nature of the Kiều Story." Vietnam Forum 3 (WinterSpring):61-98.

HessNeY, Richard C. 1979. "Beautiful, Talented, and Brave: Seventeenth-Century Chinese Scholar-Beauty Romances." Ph.D. diss., Columbia University.

Hồ BIẺU CHÁNH [Hồ VĂN TRUNG]. [1909] 1913. U tình lục [Story of secret love]. Saigon: Nhà in F. H. Schneider.

[Hó Vă Trung], trans. [1910] 1990. Tân soạn cố tích [New collection of old stories]. Saigon: F. H. Schneider.

[1912] 1919-20. Ai làm đựọc [Who can do it?]. Serialized in Nông Cồ Mín

Đàm [News on agriculture and commerce], beginning on March 20, 1919. 
[1922] 1988. Ai làm đüóc [Who can do it?] [Revised version of 1912 novel]. Hồ Chí Minh City: Tiền Giang.

. [1922] 1988. Chuá tàu Kim Qui [The ship captain of Kim Qui]. Hồ Chí Minh City: Tiên Giang.

—. [1923] 1961. Cay đáng muì đò̀i [The bitterness of life]. Saigon: Sông Kiên. [1926] 1983. Ngọn có gío duà [Blades of grass tossed by the wind]. Paris: Institute de l'asie du sud-est.

- N.d. Đồ của tôi $[$ [My life]. 3 vols. Typescript.

HoÀI ANH. 1988. "Văn học Nam Bộ trúỏc cách mạng tháng tám" [The literary culture of the South before the August revolution]. In Văn boc Nam Bộ tù đầu đến giưa thế ky XX (1900-1954) [The literary culture of the South from the beginning to the middle of the twentieth century (1900-1954)], edited by Hoài Anh et al., 7-214.

HoÀi ANH, Thành NGUYên, and Hò Sĩ Hiṭ̂p, eds. 1988. Văn học Nam Bộ tù đầu đến giüa thế ky XX (1900-1954) [The literary culture of the South from the beginning to the middle of the twentieth century (1900-1954)]. Hồ Chí Minh City: Published by City of Hồ Chí Minh.

HoÀng Ngợ PHÁCH. [1925] 1963. Tố Tâm: tâm lý tiêu thuyết [Pure heart: A psychological novel]. N.p.: Thanh Xuân.

HuỲNh MINH. 1969. Gò Công: xủa và nay [Gò Công: in old and current times]. Saigon: Cánh Băng.

LÊ HOÀNG MỦU. 1918. Oán hồng quần [Beautiful women are resented (by fate or heaven)]. Serialized in Lục Tĩnh Tân Văn [News of the six provinces], beginning on October 10, 1918.

LÊ THANH. 1942. Cuộc phỏng vấn các nhà văn [Interviews with writers]. Hanoi: Đời Mó́i.

Link, E. Perry. 1981. Mandarin Ducks and Butterflies: Popular Fiction in Early Twentieth-Century Chinese Cities. Berkeley and Los Angeles: University of California Press.

Liu, James J. Y. 1967. The Chinese Knight-errant. Chicago: University of Chicago Press.

MARr, David. 1971. Vietnamese Anticolonialism. Berkeley and Los Angeles: University of California Press.

NGUY Ề Đìn CHIẺU. [Ca. 1860] 1973. Lục Vân Tiên truyện: tường giải [The story of Luc Vân Tiên: annotated]. Ed. Ngọc Hồ and Nhât Tâm. Saigon: Sông Mói.

NGUYẾN DU. [ca. 1800] 1983. Truyện Kiều [The tale of Kiều]. Bilingual edition edited and translated by Huyǹh Sanh Thông. New Haven: Yale University Press.

NGUYếN Huệ CHI. 1986. "Ngưòi và văn Hoàng Ngọc Phách" [The life and work of Hoàng Ngọc Phách]. Tạp Chi Văn Học 5:130-37.

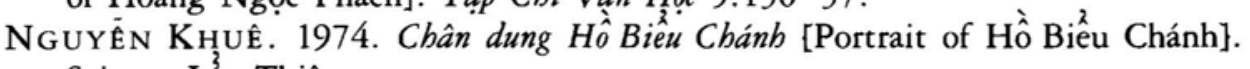
Saigon: Lủa Thiêng.

NGUYẾN Q. THÁNG. 1990. Tiến trình văn nghệ Miền Nam [The progress of arts and letters in the South]. Hồ Chí Minh City: Nhà Xuất Bản Tồng Hộp An Giang.

NGUYÉn TRONG QuẢN. [1887] 1989. Truyện Thầy Lazaro Pbiền [The Story of Lazaro Phiền]. In Văn [Literature] No. 3:115-22. Reprinted also in Nguyến Văn Trung (1987), 36-60. 
NGuYên Trọng Thuạtr. [1925] Qúa dủa đỏ [The red melon]. Saigon: Sống Mói.

NGUYỄN VăN TRUNG. 1987. Nhüng áng văn chủỏng quî́c ngü đầu tiên [Some early works in the national script]. Hồ Chí Minh City: University of Hồ Chí Minh City.

Nhát Linh [NGUYên TỨONg TAM]. 1925. Nho phong [Confucian manners]. Hanoi. N.p.

—_. [1934] 1971. Đoạn Tuyệt [Breaking away]. Saigon: Đò̀i nay.

Phạm Thé NGŨ. 1965. Việt Nam Văn học sủ giản ủóc tân biên [Concise modern history of Vietnamese literature]. 3 yols. Saigon: Quốc Học Tùng Thủ.

Phạm QUỲnh. 1921. "Bàn về tiêu tuyết" [A discussion of the novel]. Nam Phong 48 (January): $1-15$.

PHạm VIỆT TUYÈn. "Đọc truyện diễn ca 'U tiǹh lục' " [Reading the verse narrative "U tiǹh lục"]. Nghiên Cúu Văn Học [Research in literary studies] 2:85-112.

Rageau, Christiane. 1979. Catalogue des Fonds Indochinois de la Bibliothèque nationale. Vol. 1, Livres Imprimés en quôc ngu: 1922-1924. Microfiche. Paris: National Library.

THÁI VăN KIỂM. 1960. Dất Việt trời nam [The Vietnamese land of the South]. Saigon: Nguồn sông.

ThanH LÃNG. 1967. Ban̉g lüọc dồ văn bọc Việt Nam [Survey of Vietnamese literature]. 3 vols. Saigon: Trình Bày.

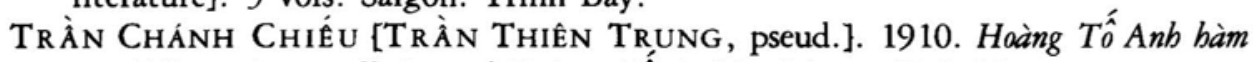
oan [The unjust suffering of Hoàng Tố Anh]. Saigon: Phát Tóan.

TrÀ̀N HUY LiệU et al. 1955-58. Cách mạng cận đại Việt Nam [Vietnam's modern revolution]. 12 vols. Hanoi: Văn sủ địa.

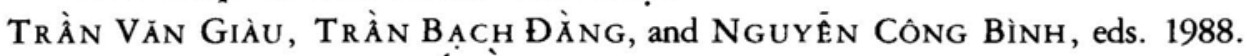
Dịa chí văn bóa thành phố Hồ Chi Minh: II Văn học [The geography and culture of Hồ Chí Minh City. Vol. 2, Literature]. Hồ Chí Minh City: Published by Hồ Chí Minh City.

TrọNG KHIÊM. 1924. Kim Anb lệsü [The sorrowful tale of Kim Anh]. Hanoi:

Đong kinh ân qúan.
TRỦóng DuY Toג̇N. 1910. Phan Yên ngọai sü-Tiết phu gian truân [An unofficial history of Phan Yên-the trials of a virtuous widow]. Saigon: F. H. Schneider.

TUǸG LÂM. 1957. Cuộc đò̀i cách mang Củòng Đê [The revolutionary life of Củờng Để. Saigon: Tôn Thất Lể. Originally a 1943 interview in Japanese with Củỏng Đề.

Vũ NGọc Phan. [1941]. Nhà văn biện đại [Contemporary writers]. 5 vols. Glendale, Calif.: Dainam. Photo reprint of 1941 edition, n.d. 